

\section{Responses of Canada's Voluntary Organizations to Shifts in Social Policy: A Provincial Perspective}

Many observers have written about the philosophical shift in Canadian politics and social policy in the last decades of the 20th century while others have looked at its impact on the voluntary sector the traditional deliverers of Canada's social programs. In this paper we explore the responses of 645 voluntary organizations to the recent policy shifts. First, we examine organizations' perceptions of and responses to these policy shifts. Then we compare differences in attitudes and actions among the provinces. Finally, we ascertain the role of economic, political, social and cultural heritage in explaining the relationship between provincial governments and the third sector. While there are national forces and trends that affect the voluntary sector, each province in Canada has a unique economic, political and cultural history that affects attitudes, actions and policy choices.

\section{A Brief History of the Evolution of Social Service Delivery}

We begin by reviewing the history of the social welfare system in Canada using Martin's (1985) four-stage, evolutionary classification:

Stage I describes the channelling of care and alms directly to those in need, without the involvement of intermediaries. This is most common in small communities and includes assistance by family members, usually female, and by individuals in the community.

Stage II evolved with the growing urbanization of society. Individuals were no longer able to come to the aid of the increasing numbers of people falling victim to poor social conditions (Rice \& Prince, 2000). Churches and charitable organizations stepped into the breach. This stage differs from Stage 1 in that care is no longer direct; help and donations are funnelled through institutions.

Stage III developed in response to the growing proliferation of smaller specialized organizations that were unable to raise the money necessary for their continued operation. Umbrella organizations, such as Community Chests, United Ways and various United Appeals were created as fundraising vehicles to support these organizations.

Stage IV represents the participation of the state in the funding and delivery of social services. This can be either in the form of direct delivery of services by the state, or as operating grants bestowed by the state to organizations to deliver those services. Often it is a combination of both.

These four stages can and do exist simultaneously in the same society, however, at different times certain types of arrangements are more prevalent than others. In the historical review of social welfare in Canada that follows, we will trace the ascendancy and decline of the different stages of social service delivery, and note the role of past historical roots and current economic and political realities in shaping policy trends. 


\section{Early settlement}

In the early settlement period, the provision of social welfare in Canada reflected the traditions of its two founding nations: France and England (Martin,1985). French settlement activity in Canada was guided by the belief that the state has an obligation to provide services to its people. Accordingly the French crown funded various organizations providing aid, educational and health services. Thus social service provision in early French Canada was predominantly a Stage IV model(direct funding by the state), supplemented by Stage II activities (individual and church groups).

\section{British conquest}

This all changed with the conquest of Quebec by the British in 1759. The British believed that the care of the poor was a Christian duty best left to individuals or church groups (Stage I and II). The social welfare net that the French crown had supported quickly disintegrated, causing "unbelievable hardships" in French Canada (Martin, 1985:60). In English Canada the indigent were always cared for by individuals and religious institutions. Eventually, as welfare needs grew the government began subsidizing aid-giving organizations (Martin, 1985). In the Atlantic colonies the opposite occurred. Locally enacted Poor Laws gave municipal governments revenues to combat poverty (Martin, 1985; McNiven, 1996). When this was not far-ranging enough, voluntary organizations were formed to fill the slack. In the sparsely populated Western provinces, governments had to play a more direct role (McNiven, 1996; Reckart, 1993).

\section{Confederation}

While Stages I and II (individuals and church groups) continued to predominate well after Confederation, governments at all levels found themselves ever more involved in the social wellbeing of their citizenry, mostly through financial support (Martin, 1985). In 1874 the Charity Act was passed, which finally recognized the work of voluntary organizations, but also gave governments the right to inspect the care-givers. By the end of the century it was accepted that state intervention was appropriate and not inimical to democracy (Wallace, 1950). The State started moving more directly into the provision of universal benefits, enacting legislation such as Workers' Compensation and Old Age Pension (Rice \& Prince, 2000). This move represented a philosophical shift from private relief to public responsibility, from targeted services to a more universal model (Martin, 1985; Rice \& Prince, 2000). During this period too, there was a proliferation of charitable organizations responding to growing needs in society and increased demographic diversity. (Reckart, 1993). Thus we see that, by the time the Depression set in, Canada had a mixed economy in terms of welfare provision, encompassing all four stages of welfare evolution with a growing role for government. Nevertheless, Stages I and II continued to be predominant well into the early 20th century. The Great Depression changed all this.

\section{The Great Depression}

With massive numbers of unemployed, and farmers rendered destitute by the falling wheat prices, local governments and charitable organizations could no longer care for the needy. The federal and provincial governments had to step in forcefully by passing a number of universal acts to provide relief and prevent a recurrence of such devastation. As a result, social services shifted from the 
private/charitable domain to the State, and provision changed from voluntary and nonprofessional to bureaucratic and professional (Rice \& Prince, 2000). The country was moving into Stage IV.

\section{The Welfare State}

In the first three post-war decades, aided by newly adopted Keynesian economic policies, Canada was enjoying unprecedented economic growth. Still in the shadow of the Great Depression, the government felt it could afford to become more heavily involved in the social welfare of their citizenry. By the 1970s the Canadian Welfare State was in place (Johnson, A. 1987). Thus Canada had come full circle from the predominance of the direct funding model (Stage IV) in the 17th century to reliance on individual and church groups in the 18th and 19th centuries, back to Stage IV in the 20th century, with government being the predominant force for social welfare. Successive Liberal governments, philosophically committed to universal social welfare, rounded out the welfare state with the enactment of a national pension and medicare plan. The welfare state represented not only the accomplishment of a social safety net to mitigate the ravages of economic downturns; it also became an instrument of unification and equalization (Smardon, 1991; McNiven, 1996; Tester, 1996; Rekert, 1993; Drache, 1995).

\section{The last two decades of the twentieth century}

The erosion of the social welfare state began, imperceptibly in the mid 1970s. As the economic recessions of the 1970s and 1980s hit, "liberal policy making stumbled between Keynesian logic and an emerging neo-classical economic sensibility" (Tester, 1996:20). With the election of a Conservative government in 1984, Keynesian economics, along with the goal of full employment, was abandoned, to be replaced by a market economy (Rice \& Prince, 2000; Tester, 1996; Smardon, 1991). Social programs were cut, and programs of privatisation and fiscal restraint were pursued. The "new" paradigm signalled a retreat from Stage IV direct government funding towards Stage I and II residualism, as provision for the needs of the marginalized were downloaded once again to individuals, church groups and community organizations.

Both the Conservative and the Liberal governments of the last two decades have been stealthily, and steadily, whittling away at the Welfare State (Tester, 1996; Rice \& Prince, 2000). With diminished federal funding, the provinces have downloaded responsibilities and cut social spending, expecting the voluntary sector and community networks to fill the vacuum, without increasing their grants. These cuts "seriously reduced the capacity for voluntary agencies to provide services" (Rice \& Prince, 2000:113). Paid positions were lost and recruitment and training had to be curtailed, Forced commercialization, introduction of fees for service, adoption of business practices, and marketing and fundraising strategies, led to mission displacement. A sense of vulnerability reduced the role of advocacy and networking for policy changes (Rice \& Prince, 2000; Meinhard \& Foster, 2000). Competition was increased as the commercialisation of public welfare services forced nonprofit service providers to compete with for-profit service providers for government contracts. The rate and extent at which these changes are occurring across provinces is different, but there is no doubt that the trend is evident in all provinces (Ismail, 1988; Hall \& Banting, 2000).

\section{Provincial Snapshots}


Two key trends that have had an impact on the development of every provincial program. First, the Federal government's cost sharing policies were instrumental in the development of social welfare programs. Second, in all provinces, irrespective of the party in power, there has been a movement away from the broad concepts of the welfare state in recent years.

\section{Maritime Provinces}

In Nova Scotia and New Brunswick the social welfare of the colonies was based on the Elizabethan Poor Laws, which were the culmination of a series of parliamentary acts specifying how the poor were to be treated. Parishes and municipalities were required to provide relief for the poor (Education Resources, 2000) without the help of the colonial government,. In PEI and Newfoundland, with their sparse populations scattered in tiny outposts, the colonial government, not the local authority, was responsible for welfare services. Because of their poverty, “... the Maritime provinces have lagged behind the rest of Canada in the provision of social assistance" (Boase, 1996:145).

In the post WWII period, provinces began playing a larger role in welfare provision, taking over welfare responsibilities from the municipalities. Social service expenditures increased in all the Maritime provinces, aided by federal cost-sharing and the institutionalization of equalization. The recent reductions in Federal transfer payments, in exchange for greater autonomy, was detrimental to the Atlantic provinces. They have always been far more dependent on transfer payments than other provinces and have been largely passive recipients of federal programs (Boase, 1996). This change combined with the recession of the 1980s led to policies of retrenchment, fiscal restraint and privatization in the Maritimes. Health, education, and welfare budgets were slashed in all provinces, though changes in per capita expenditure in Newfoundland were not as severe. In Nova Scotia, New Brunswick, and PEI government administration was redesigned so more welfare responsibilities were devolved to the community-level, including the voluntary sector. The sector was also burdened by increased competition from the for- profit community as government expanded privatization beyond the nonprofit sector, purchasing service contracts with service providers from both sectors. In the latter half of the 1990's, some social spending was restored in PEI but unlike New Brunswick there was no subsequent upswing in expenditures. Cuts in New Brunswick were also more gradual than other provinces such as Nova Scotia, for example, which had a steep decline in expenditures in the 1990's and did not recover previous levels until 1999. In Newfoundland, there were further cuts in the late 1990's however, investment in health care and education continued as did the battle against unemployment. See Figures 1 - 4.

\section{$<$ Insert Figures 1-4 here>}

\section{Quebec}

As described in the first section of this paper, the early settlements in French Canada had a Stage IV (direct government funding) social welfare system in place from 1685 until the time of the British conquest in 1759. With the defeat of the French, English Common Law was applied and governmental support of social services for the needy was discontinued. The social assistance model reverted to Stages I and II (individuals and church groups). This remained in place, more or less until the end of the Second World War. 
Concerned with infringement on its provincial jurisdictions, successive Quebec governments rejected cost-sharing and federal social programs, forsaking large sums of federal funding. This changed after 1960 and the Quiet Revolution. The move from Stage I and II residualism to the Stage IV welfare state of the post-war era was perhaps most marked in Quebec. The expansion of Quebec's social welfare state continued well past most of the other provinces in the belief that social policy was important in preserving the unique culture of Quebec (Boase, 1996). Even during the volatile 1990s, that saw significantly decreased spending, the prevailing philosophy of the Quebec government was one of fiscal retrenchment but continued state involvement (Jensen \& Phillips, 2000). See Figure 5.

\section{Ontario}

$<$ Insert Figure 5 here $>$

When Quebec was split to create Upper and Lower Canada in 1791, in Upper Canada (Ontario), social relief was seen to be as outside the realm of government (Mishra et al., 1988), solidly adhering to a residualist Stage I and II (individuals and church groups). However, Ontario's government soon found itself more heavily engaged in philanthropy and by 1874 the Ontario Public Charities Act was passed, which provided "public funds for private institutions performing welfare functions" (Chandler \& Chandler, 1979:193). From that point on, the history of Ontario's welfare is one of increasing provincial government participation in the funding of social services delivered at the community level by voluntary organizations (Mishra et al., 1988). Ontario was the first province in Canada to establish a Department of Public Welfare and readily opted into federal-provincial cost sharing programs. The government became a key player not only in the funding of social services, but also in their delivery (Lang, 1974; Struthers, 1994; Mishra et al., 1988).

As early as the mid-1970s, however, the Conservative government of Ontario adopted a "clear ideological commitment to the privatization of social welfare" (Mishra et al., 1988:134). This trend was reversed by successive Liberal and NDP governments, until the "common sense revolution" of the early 1990s, when a "hard right turn" was legislated by the new Tory government (Jeffrey, 1999). Massive cuts to social budgets were instituted and the provincial government withdrew many direct services to the public. Voluntary organizations were expected to take up the slack, even as their funds were being slashed (Baker, 1996). Social service provision was opened up to the proprietary sector, putting even greater strain on the nonprofit sector (Brezanson, 1998). Figure $6^{\mathrm{i}}$ clearly indicates the steep decline in per-capita social expenditures in Ontario since the Tories came to power.

\section{$<$ Insert Figure 6 here>}

\section{Manitoba}

As in the rest of Canada, Manitoba's early attitude towards welfare was residualist, Stage I and II models (individuals and church groups). Social reform ideas were introduced as early as the 1890s, by the newly formed Labour Party representing the growing urban centre of Winnipeg. By 1915 their demands for compulsory education, minimum wage laws, and the abolition of child labour were all passed into law. However, the period between the two world wars was marked by an economic decline in which spending on welfare, schools and hospitals was reduced (Peterson, 1997). 
It wasn't until 1958, in keeping with the Keynsian philosophy of that time, that social welfare spending was increased and government's role expanded.

The modern political history of Manitoba is characterized by swings between the NDP and the Tories. These swings reflected opposite social welfare policies. During his first term in office, NDP Premier Ed Schreyer (1969-1977) demonstrated his commitment to the principles of democratic socialism by enacting many long awaited social changes (Robin, 1978). During this period, Manitoba allocated a greater proportion of its budget to social welfare than any other province (McAllister, 1984). Schreyer's successor, Sterling Lyon (1977-1981), a neo-conservative, introduced extreme restraint which led to a decrease in social and health services and a limited hospital grants. The population rejected this minimalist government approach by resoundingly defeating Lyon and electing Howard Pawly, leader of the NDP (1981-1988). At a time when global trends were increasingly tilting towards right wing politics, Manitobans opted for a government strongly supportive of the welfare state (Bracken \& Hudson, 1988). This ended with the election of PC Gary Filman in 1988 who embraced a pro-business policy of fiscal conservatism, cutting $\$ 12,000,000$ in grants to nonprofits, (Dyck, 1996). Figure $7^{i}$ shows the trend in social expenditures for Manitoba in the decade of 1990. Interestingly, the curve is almost identical to that of New Brunswick, a province with a much different economic, political and cultural history.

$<$ Insert Figure 7 here $>$

\section{Saskatchewan}

The early development of Saskatchewan was characterized by the formation of cooperatives for protection from environmental hazards. They included grain elevators, retail stores, and health facilities (Dyck, 1996). Successive Liberal governments from 1905 to 1929 passed legislation that provided credit to farmers, education to new immigrants, urban housing, and the beginning of government social programs (Smith, 1974). By the end of their 24 year tenure, they had instituted mother's allowance, set up a child welfare bureau, built hospitals, increased old age pensions and established vocational schools

Of all the Canadian provinces, Saskatchewan was the most devastated by the Great Depression and government stepped in to provide relief. After WWII the Cooperative Commonwealth Federation (CCF) under the leadership of Tommy Douglas, introduced a myriad of innovative in social policies especially hospital and medical insurance, and other health services, which served as models for other provinces and eventually the federal Medicare Act (Silverstein, 1968; Boase, 1996). During this period, Saskatchewan's budget allocation for welfare exceeded that of any other province (Silverstein, 1968). These programs remained in tact and even grew through successive governments, until the 1980s, when the focus changed to deficit reduction and a massive program of privatization (Pitsula \& Rasmussen, 1990; Dyck, 1996). This led to substantial cuts in social, health and education spending, including the elimination of provincial grants to many nonprofit social service agencies. As a result, private charities were called upon to help meet the social needs of the province (Pitsula \& Rasmussen, 1990). By mid 1990 the deficit was halved and spending actually rose in welfare and social services, especially with respect to child poverty (Dyck, 1996). Examination of Figure 8 indicates that in the last 10 years Saskatchewan has had the steadiest social spending record of all provinces. Fiscal conservatism was tempered by a social conscience. 
$<$ Insert Figure 8 here $>$

\section{Alberta}

The early political history of Alberta was characterized by alternations between conservative and reformist parties. Regardless of the party, there was a constant struggle with the Federal government over control of natural resources (Friesen, 1999; Government of Alberta, 2001a). Social services were provided mostly by volunteers which was not enough to fight the ravages of the Great Depression. This was mandated to the Social Credit Party that promptly introduced legislation to overhaul the banking system, redistribute income by giving every household a $\$ 25$ "social credit", establish medicare and state control over industry (Hesketh, 1997; Pal, 1992). Most of these initiatives were disallowed by Ottawa on constitutional grounds.

As in other provinces, the post-WWII years were ones of unprecedented prosperity which led to increased social spending despite fiscal conservatism (Caldaro, 1979). During these years, a shift in welfare philosophy occurred, from a concentration on custody and maintenance to a "focus on prevention and the social development of the individual" (Hornick, et al., 1988:47). Alberta's booming economy in the 1970s allowed the province to opt out of certain federal-provincial cost sharing programs and establish its own criteria, such as allowing for-profit day care providers to compete for daycare funding. Despite this, social welfare advances were limited, even as health benefits increased (Hornick et al. 1988). The economic boom finally burst with the OPEC oil crisis of 1983. Welfare rates were cut and Alberta began looking inwards on how to reduce public administration costs and downsize government (Nikiforuk, et al., 1987; Tupper, 1996). There was a shift to community responsibility, weaving private philanthropy into social welfare policy and began a program of privatization, including the use of for-profit organizations in social service delivery. More recently the conservative government made severe cuts in expenditures, revamped government bureaucracy to make it more business like, and introduced a program of privatization (Tupper, 1996; Shedd, 1997). By both Albertan and Canadian standards, this policy was seen as radical. Figure $9^{i}$ depicts these steep cuts.

\section{$<$ Insert Figure 9 here>}

\section{British Columbia}

In the rest of the British colonies in Canada, the social welfare of citizens was left mostly to family/community networks and charitable organizations, with government intervention evolving slowly. In British Colombia, however, public social services were implemented earlier both because of the needs of remote, isolated settlements, and because of the tradition of government involvement in the physical development of the province (Cassidy, 1945). This may explain why BC has a "reputation as a province with advanced social legislation" (Cassidy, 1945:52) and "typically had more generous social assistance" (Boase, 1996:453), despite the fact the its general model was Stage I and II residualism (Prince, 1996; Reckart, 1993). There was still no direct participation in service delivery by the government (Reckart, 1993). As a result of the Great Depression, the federal government became more involved the welfare of all Canada's citizens. 
The post-WWII years saw the creation of the modern health care system, post-secondary education and income security, mostly put into place during the 20 year tenure (1952-1972) of the Social Credit government. During this period several federal social policy initiatives were enacted and at the same time, BC's Government was expanding its vision of social services (Callahan \& McNiven, 1988). A partnership was evolving between government and the voluntary agencies that led to the rapid growth of the voluntary sector. Voluntary organizations were now used to extend the services of government. This all changed in the early 1980s with the introduction of a program of restraint. Welfare benefits were decreased and the Community Resource Board was dismantled. As the economy picked up in the latter half of the decade, fiscal restraint was eased and funding to some areas was increased (Dyck, 1996; Scarf, 1996). Although spending was slowed down, in the 1990s, the social infrastructure was expanded incurring large deficits. Figure $10^{\mathrm{i}}$ shows the social expenditure trends of British Columbia over the last 10 years. In the latter half of the decade, BC averages the highest per-capita social expenditure.

$<$ Insert Figure 10 here>

\section{The Current Situation - The 1990s}

As discussed previously, the defining characteristic of the 1990s has been the shift to more neoconservative policies particularly in the age of social welfare (Jeffrey, 1999; McBride \& Shields, 1997; Evans \& Shields, 1998; Hall \& Banting, 2000). Figures 11 to 20 graphically depict the percent change in social expenditures from 1993 to 2000 for each province. Because our data on voluntary organizations was collected in 1998 and 1999, we are most interested in the funding situation leading up to that time period.

These figures are helpful in understanding the role of national perception and provincial reality in shaping the voluntary sector's perspective on the external environment. Comparing the funding situation across the provinces, it is clear that Nova Scotia, Ontario and Alberta have experienced the most dramatic cuts to funding levels using 1993 as the base year, cumulatively between 20 and $27 \%$. While Ontario and Alberta have continued to fund at this lower level, Nova Scotia has increased its funding back up to 1993 levels. This suggests that any adaptation the voluntary sector has made in coping with significantly decreased social expenditures have had to become permanent changes in Ontario and Alberta.

Cumulatively, PEI, Quebec and Manitoba have experienced decreases of between 10 and 15\% in social expenditures in the 1990s, while New Brunswick, Newfoundland and British Columbia have only had decreases between 5 and $10 \%$. Saskatchewan is the only province to have steady levels of social expenditures during the 1990s. With the exception of PEI and British Columbia, the other provinces began to increase funding levels in the latter part of the decade to approach 1993 levels.

\section{Summary of Historical Context}

These "snapshots" underline many similarities among the provinces, with the pendulum swinging from restraint to spending to restraint. Throughout Canada, in the early years of confederation, a residualist Stage I and II model of welfare prevailed, although some provinces were more involved in the citizen's welfare from an earlier period than others. After World War II, all of the provinces, 
driven by Keynsian concepts, economic prosperity and federal government transfer payments, experienced an expansion of the welfare state. Through a system of equalization payments, the "have-not" provinces were able, for the first time, to provide their citizens social services commensurate with the richer provinces. As the years progressed, all provinces began operating on deficits and were incurring large debts. On a national basis, the federal government also reduced block grants and put limitations on transfer payments that served to decrease federal support for the social welfare system (Tester, 1996). At the same time the new system provided more freedom for provinces to invest these funds (Torjman, 1996). It is in the timing and depth of the responses to these deficits that the provinces differ the most. The next section of this paper will present data from the survey of 645 voluntary organizations.

\section{Survey of Voluntary Organizations}

\section{Research Questions}

This study was designed to discover how Canadian voluntary organizations are responding to the significant policy changes that are occurring in their provinces. A 120-item fixed response questionnaire probed how the organizations perceived the changes in the environment, what impact these changes were having on their organizations and their clients, how they are responding to these changes organizationally and how they view the future of the voluntary sector and social services in Canada.

\section{Sample}

This study was conducted on a sample of 645 leaders of voluntary organizations from across all provinces in Canada. The sampling framework was based on a proportional representation of nonprofit organizations from the larger provinces, Quebec, Ontario and British Columbia, and a minimum of at least 25 organizations from the smaller provinces in the Maritimes and the Prairies. In order to control for organizational size and organizational mandate, both of which may have an effect on perceptions of and responses to environmental changes, we tried to ensure that there would be an appropriate distribution of small, medium and large organizations in each province as well as a representative mix of social/community service, health and education/advocacy organizations. (See end note 1 and 2.)

<Insert Tables 1-3 here>

\section{Data Collection}

Since there is no comprehensive list of nonprofit organizations in Canada, several sources were used as a basis for contact lists: NAC membership list; Revenue Canada list of Charitable organizations; Community Blue books; Internet listings. Trained interviewers conducted interviews with the leaders of organizations that qualified to be in our sample. Through the careful use of quotas on key organizational features - province, size and mandate - we feel that we achieved a satisfactorily representative sample. 


\section{Data Analysis}

SPSS Version 9 was used to create scale scores and analyze the data. Some scales were simple additive scales based on the sum of individual item responses. For most scales, factor analysis was used to identify clusters of related variables. Comparisons between provinces were done using oneway analyses of variance. Duncan's homogeneous subsets were used to determine which provinces or groups of provinces had similar responses.

\section{Provincial Responses}

\section{Perception of the environment}

Our first area of interest was learning how executive directors of nonprofit organizations were reacting to the changes taking place in their provinces and in the country as whole. As we have seen, there has been a change in policy, a shift to privatization and devolution in most provinces, and in almost all cases, this policy shift has been accompanied by cuts, quite drastic cuts in some provinces. Table 4 records the responses, on a 5 point Likert scale, of each province to a series of questions. An additive index was created to indicate the general trend of each respondent. The scale midpoint of the index, indicating neither satisfaction nor dissatisfaction, is 21 . Not a single province scored below or even close to the midpoint, indicating that executive directors of voluntary organizations across Canada are dissatisfied with the shifts in policy and the way they have been implemented.

Duncan's test for homogeneous subsets for alpha $=.05$ identifies a subset which excludes Saskatchewan and Ontario; Saskatchewan scoring significantly lower than the homogenous subset of provinces and Ontario scoring significantly higher. Nova Scotia and Ontario make up a third subset, significantly different from the rest of the provinces. In all subsequent analyses, whenever mention is made of provinces or groups of provinces differing significantly from the others, it refers to the results attained through Duncan's test for homogenous subsets for alpha $=.05$.

\section{<Insert Table 4 here>}

Although all provinces are dissatisfied with the current environment, Saskatchewan is the least dissatisfied. This is consistent with provincial differences in funding, in that Saskatchewan was the only province to have steady social funding throughout the 1990s (see Figure 18). This meant that voluntary organizations in Saskatchewan did not have the same challenges as organizations in Ontario, Alberta and Nova Scotia where budget cuts were quite dramatic in a short period of time.

Nova Scotia is an interesting case. Although by 1999 its social spending had regained 1993 levels, the perception was still a negative one. The Liberal government of John Savage had frozen salaries, imposed premiums on drugs and had begun a process of privatization (Clancy et al., 2000). Despite a steady increase in social expenditures, these policies were still driving the perceptions of the respondents.

What is surprising is that Alberta, whose cuts were even steeper than Ontario's (see Figures 9 and 
19), was not significantly different from the rest of the provinces in dissatisfaction with the external environment. This may be attributable to the Albertan culture of independence and private enterprise (Pal, 1992; Caldaro, 1979). On closer examination of Table 4, Alberta was one of only three provinces to approve of the shift of responsibility for social service to the community.

\section{Impact on the organization of environmental changes}

Table 5 lists the various kinds of impacts the organizations felt as a result of the changes. Respondents were asked to indicate how strongly their organization felt various impacts, from "feel not at all" to "feel very strongly". There were statistically significant provincial differences on all but two impacts: feeling a greater need to address inefficiencies in the organization and feeling the need to participate in for profit activities to support nonprofit work.

From this table we ascertain that the most strongly felt impact of the devolution and funding cuts among all respondents was an increased demand for services from client groups. Prince Edward Island and Newfoundland were least likely to experience this, perhaps in part because of their small population and traditional lack of significant population growth. Nova Scotia and Alberta were the most likely to feel this increased demand, in part because the dramatic cuts in social funding in these two provinces may have caused some service-delivery organizations to close. It seems likely that the cuts resulted in a contraction of the sector as these two provinces were significantly more likely to indicate that they felt the need to cover areas previously taken care of by other organizations. Interestingly, while Ontario and Quebec also had means higher than the average for the total sample on feeling increased service demands, they were average or lower than average on feeling the need to cover services previously delivered by others. This suggests that the demand felt in Ontario and Quebec may have resulted from more people requiring services rather than organizations closing. Certainly, for example in Ontario, decreased welfare payments may have added to the client lists of voluntary organizations (Jeffrey, 1999).

The second most strongly experienced impact reported was an increased demand for accountability. New Brunswick and New Prince Edward Island were significantly less likely to experience this than were other provinces. Interestingly, these same two provinces were the least likely to feel the need to make better use of staff resources and to address inefficiencies in the organization suggesting that adopting a more "business-like" perspective was not the preferred method for addressing the fiscal crisis.

Recognizing the need to make better use of staff skills ranked third. Quebec was the most likely to feel this impact, as well as the increased demands for accountability. It was also higher than average on addressing inefficiencies which suggests that voluntary organizations in this province were concentrating on their operations as a way of adapting to the external environment.

Fourth ranked was an increased sense of vulnerability. Once again, New Brunswick and New Prince Edward Island felt least vulnerable, whereas Ontario and Nova Scotia felt most vulnerable. Consistent with their feelings of security, New Brunswick and PEI were the least likely provinces to feel that funders did not have their client needs as a priority. In contrast, Ontario respondents were most likely to feel their clients were not important to funders. This suggests that feelings of vulnerability may be linked to the congruency of the organization's mandate with the policy 
priorities of funders, especially the government. In Ontario, with the advent of the "Common Sense Revolution", the focus of government shifted almost exclusively to deficit reduction and for bolstering the economy through tax cuts and cost efficiencies. Social programs were much farther down the list of priorities (Boase, 1996; Moscovitch, 1997).

The impacts of funding and policy changes are less keenly felt by voluntary organizations in the three smallest provinces. These smaller provinces have fewer large urban centres and the tighter social integration of smaller communities may mitigate the impact of policy changes. It is not surprising that voluntary organizations in Ontario and Nova Scotia were feeling the most vulnerable. They had recently been subject, and in the case of Ontario, still subject, to steep cuts accompanied by policies that in the case of Ontario, were revolutionarily different from the past (Brezanson, 1998). In the case of Nova Scotia, although social spending was already on the increase, the government of the time was engaging in significant redesign of health and social service delivery, which may have increased the trepidation of leaders of voluntary organizations (Clancy et al., 2000). Once again, despite the deep cuts in Alberta, voluntary organizations did not feel as vulnerable; perhaps because the changes were not as unprecedented as in Ontario and Nova Scotia. Voluntary organizations in both Alberta and Nova Scotia felt increased demands for services, as provincial social budgets were being slashed and delivery systems were changed.

Although forced collaboration or amalgamation, the need to cover service areas of other organizations and funders not thinking of clients as a priority were not felt very strongly by respondents overall, there were significant differences among provinces. Newfoundland was most likely to feel the need to amalgamate and New Brunswick was the least likely to report this impact. The geographic dispersion of the population in Newfoundland may account for the strength of this feeling of being forced to amalgamate. The need to cover other service areas was most likely to be felt by Nova Scotia and least likely by Quebec. Once again the policies and actions of the Nova Scotia government may have intensified the impact of devolution among the voluntary organizations in that province. Quebec and Ontario were most likely to feel that funders didn't have their clients as a priority, whereas New Brunswick was least likely to mention this as an impact. As Canada's largest and most urbanized provinces, there are probably greater gaps between the well to do and the marginalized in Ontario and Quebec which affects policy priorities.

The findings seem to suggest that while the overall impact of the external environment may be determined by broad-based perceptions of devolution and funding cuts, the intensity with which these impacts are felt may be tempered by the particular economic and political situation in each province as well as its social and cultural heritage.

\section{$<$ Insert Table 5 here>}

\section{Organizational changes made in response to the changing environment}

Respondents were asked to indicate, on a scale of 1 - 5 from "not at all" to "substantially" whether they had undertaken any strategic or organizational changes in the past two years in response to the environmental changes. Fourteen various strategies were listed. Factor analysis, using principle component analysis and varimax rotation converged in eight iterations to reveal four factors. (Three items loaded almost equally on three factors. These items were not included in any of the four 
factors.)

The first factor relates to what we called strategic staffing issues: reassessing hiring criteria, putting greater emphasis on performance evaluations, putting more emphasis on volunteer recruitment and working more closely with other organizations. Although this last statement is not directly about staffing, working more closely with other organizations can be seen as reducing the need for staffing. The mean score on the index was slightly higher than the scale midpoint, indicating that these were strategies engaged in by organizations at least to some extent.

The second factor, which we called downsizing, includes two variables: reducing full time staff and reducing services. The mean score on the index was lower than the scale midpoint, indicating that downsizing wasn't an option engaged by most organizations.

The third factor relates to business orientation and is comprised of the variables: increasing focus on marketing, working more closely with private sector organizations and seeking board members with business skills. The mean score on this index was above the scale midpoint, indicating that organizations are to some extent engaging in more business-like behaviour.

The last factor, which we called the revenue strategies includes two variables: engaging in commercial ventures and diversifying funding sources. The mean score on this index is below the scale midpoint, mostly because organizations are not engaging in commercial ventures, although they are diversifying funding sources.

\section{$<$ Insert Table 6 here>}

Significant differences among the provinces were found for the Business Orientation factor $(\mathrm{F}=2.21$; $\mathrm{df}=9,617 ; \mathrm{p}=.02)$ and the Revenue Strategies factor $(\mathrm{F}=1.86 ; \mathrm{df}=9,618 ; \mathrm{p}=.05)$. Overall, the respondents reported an increase in adopting a more business-like orientation. Organizations in only two provinces, Prince Edward Island and Manitoba reported no increase in business-like activities. Duncan's homogenous subsets identified three provinces in which business orientation was significantly higher than the rest of the provinces. These were British Columbia, Ontario and Alberta, not surprisingly the three provinces that have a history of entrepreneurial and corporate enterprise.

Although there were significant differences among the provinces with respect to Revenue Strategies, overall, voluntary organizations did not experience an increase in funding diversification and commercial ventures. The only province that actually reported an increase in these activities was Alberta. Duncan's analysis showed it to be excluded from the homogeneous subset. This is not surprising given Alberta's emphasis on self-sufficiency and for-profit private sector activities. Manitoba, New Prince Edward Island and Newfoundland scored significantly lower than the other provinces on this factor.

There were no significant differences among the provinces on either of the other factors. Overall, organizations in Canada did not engage in significant downsizing activities. The mean score on this factor (5.66) was below the index midpoint of 6. Only Quebec scored above 6, indicating that the response categories for the majority of the provinces was in the "not at all " range. Table 5 showed 
that organizations were feeling an increased demand for services, so it is likely that downsizing was not an option. Voluntary organizations across the provinces also did not differ significantly in terms of staffing issues. The overall mean (12.5, midpoint - 12) indicates that most organizations were "somewhat" engaged in strategic staffing over the previous two years.

\section{Inter-organizational relations}

Respondents were asked a series of questions about whether they engage in inter-organizational relationships ranging from occasional discussions, regular meetings, membership in an umbrella organization, participation in a network, short term coalitions, long term joint ventures to mergers. A count was taken of all the different kinds of inter-organizational activities reported by each organization (Table 7). A significant difference was found among the provinces $(\mathrm{F}=2.32 ; \mathrm{df}=9,631$; $\mathrm{p}=.014$ ). However, the assumption of homogeneity of variance was rejected using the Levene statistic. Consequently we tested the differences in inter-organizational relationships among the provinces using the Kruskal-Wallis test for $\mathrm{K}$ independent samples. This test confirmed the significant difference found in the ANOVA analysis (Chi $\mathrm{Sq}=23.36, \mathrm{df}=9, \mathrm{p}=.005)$. Based on this confirmation, we feel that it is safe to refer to Duncan $[$ s homogenous subsets to investigate where the significant differences are expressed. Voluntary organizations in Ontario engage in significantly more numerous inter-organizational contacts than the subset of the other provinces. At the same time, New Brunswick and Manitoba engage in significantly fewer contacts that the rest of the provinces. Given that Ontario has the greatest number of voluntary organizations in Canada, it is not surprising that they have a more developed inter-organizational network.

\section{<Insert Table 7 here>}

We were not only interested in the extent of inter-organizational behaviour, but also in learning what motivates organizations to seek collaborations and partnerships. Out of a list of eight items presented to the respondents, the three key motivating factors were: gaining attention for causes through strength in numbers, achieving greater community involvement and providing more integrated services. The two items ranked lowest as motives for collaboration were: becoming more independent from the government and satisfying government requirements for funding. Interestingly, the highest ranked items are reasons linked to fulfilling mission and mandate suggesting that the organization is in control. The lowest ranked items have to do with external influence on decision-making. These findings are consistent with Table 5's that indicated most organizations did not feel forced collaboration was an important impact of the changing external environment.

\section{<Insert Table 8 here>}

We were also interested in how respondents perceive collaborations. What did they actually think about different aspects of collaboration? In order to find out, we asked respondents to rate a series of 11 statements about various aspects of collaboration on a five point scale ranging from strongly disagree to strongly agree. Factor analysis was used to find underlying commonalities among the various items. Principal component analysis using varimax rotation converged after six iterations. Four factors were identified. 
The first factor was labeled predisposing conditions for collaboration and was comprised of two items: collaborative arrangements are less appealing to organizations when times are good and collaborative enterprises are less important for organizations that are financially independent. The mean score on this index was slightly above the scale midpoint of six, indicating general agreement. There were significant differences among provinces $(\mathrm{F}=2.28 ; \mathrm{df}=9,616 ; \mathrm{p}=.019)$. All provinces, except Quebec agreed that collaborative arrangements are less appealing in good times and less important for financially independent organizations. Newfoundland, Manitoba and Saskatchewan were the most likely to agree to those statements. With resource-based economies, these three provinces may have more experience in living with the swings between good times and bad times, and thus felt more comfortable agreeing with these broad statements.

The second factor was comprised of three items: the perception that it is easier to collaborate with organizations run by women, organizations with a collective structure are easier to partner with and large organizations use partnerships to build empires. We called this factor structural bias because all of these statements relate to aspects of organizational size and structure. Most respondents didn't agree with these statements, the mean (8.47) was below the scale midpoint. There were significant differences among the provinces $(\mathrm{F}=1.90 ; \mathrm{df}=9,575 ; \mathrm{p}=.049)$, but they were not delineated in Duncan's test of homogeneous subsets. While respondents believe that structural characteristics have no impact on the success of collaborations, this belief may be influenced by their paucity of experience with collaborative arrangements. They may not see trends, if they do in fact exist, because of a lack of personal data.

The third factor that we labeled collaborative complementarity, is comprised of three items important for successful collaboration: shared purpose, common values and complimentary skills. The mean score on this index (11.4) was well above the scale midpoint of 9 indicating that organizations agree with the three items in this index. There were no significant differences among provinces.

The fourth factor relates to competition. The items express the belief that: competition can have a positive impact and organizations should seek a competitive edge. Respondents in Quebec were the only ones to disagree with this competitive outlook. Respondents in the rest of the country indicated agreement with these statements, the mean score of 6.63 was above the scale midpoint of 6 . ANOVA analysis indicated significant differences among provinces ( $\mathrm{F}=2.83 ; \mathrm{df}=9.614 ; \mathrm{p}=.003)$. Duncan's subsets indicate that Quebec scored significantly lower than other provinces. It may be that in Quebec, voluntary organizations have more of a social/nationalist perspective, and are therefore less sold on the idea of competition, the new mantra of the times. Ontario, Newfoundland and New Brunswick scored significantly higher than the rest. This positive view of competition may be linked to the efforts achieved by the two Maritime provinces to diversify their economies and compete globally.

<Insert Table 9 here>

\section{Future outlook}


Finally respondents were asked how the viewed the future. Fourteen statements were read to them about the future of the voluntary sector in Canada. They were asked to indicate the level of their agreement with the statement on a five-point Likert scale ranging from "strongly disagree" to "strongly agree". The items were factor analyzed to give a more comprehensive picture. Five factors were extracted using principle component analysis with varimax rotation.

The first factor contained four statements expressing the belief that in the future: there will be fewer small organizations, the situation for marginalized groups will become worse, more organizations will be merging, and governments will try to exert more control over the actions and priorities of the voluntary sector. Because of the pessimistic nature of these statements, we labeled this factor the pessimism factor. The mean score on this factor was 14.2, well above the scale midpoint of 12 , indicating the general pessimism of the executive directors of Canada's voluntary sector organizations in all provinces. There were significant differences among the provinces on this factor $(\mathrm{F}=3.79 ; \mathrm{df}=9,607 ; \mathrm{p}=.000)$. Duncan's homogeneous subsets indicate that Ontario is significantly more pessimistic than the rest of the provinces. This is not surprising given that from 1993 to 1998, social expenditures in Ontario declined successively in each year (See Figure 16). Given this experience, the voluntary sector would be more likely to see the lack of support as a long-term trend rather than a short-term policy shift. Saskatchewan is the least pessimistic of the provinces. This comparatively low level of pessimism is consistent with Saskatchewan's having stable social funding throughout the decade (See Figure 18). In addition, the actions of the government at this time, demonstrated that it was possible to retire the debt and still maintain the social safety net (Brown et al., 1999; Dyck, 1996).

The second factor that emerged contained three statements expressing the belief that: organizations will take on a more active role on behalf of the sector, clients will be more involved in the decision making aspect of the voluntary organizations, and voluntary organizations will devote more time towards building a civil society. We labeled this factor community activism. The mean score on this factor (10.9) was above the scale midpoint of 9, indicating general agreement that in the future there will be more community activism. There were no significant differences between the provinces.

The third factor that emerged contained two items, the belief that: as the economy gets better, governments will revert back to their previous levels of support, and in the future there will be greater appreciation of the voluntary sector. We labeled this factor the optimism factor. The mean score on this factor (5.89) was below the midpoint of 6, indicating general lack of optimism. These results are not surprising given the previous finding about the pessimism of voluntary organizations about the future. There were significant differences among the provinces on this factor $(\mathrm{F}=3.18$; $\mathrm{df}=9,612 ; \mathrm{p}=.001)$. Six out of the ten provinces scored below the midpoint, with Ontario registering the lowest, followed by Manitoba. Ontario has not only had to deal with reductions in social expenditures, but also significant policy initiatives in education, health and the environment. Given some unanticipated negative consequences of devolving responsibility for key services (eg. Walkerton e-coli crisis), it is understandable that Ontario respondents would be the least optimistic about future increases in government support and the role of the voluntary sector in the future. In Manitoba, the voluntary sector and the government have always had a good relationship, regardless of the party in power (Bracken \& Hudson, 1988). However, successive cuts in social spending from 1994 to 1998 may have undermined the partnership. The four provinces that seemed to be 
cautiously optimistic, scoring slightly above the midpoint, were Quebec, Alberta, Nova Scotia and New Brunswick, with New Brunswick being most optimistic. The contrast between Alberta and Ontario is interesting. While both provinces have introduced revolutionary changes and cut spending drastically, in one there is relative optimism about eventually restoring things to the way they were before, and in the other there is clearly none. Perhaps in Alberta there is greater confidence in the government especially now that there is an oil boom. Nova Scotia, with its history of deep cuts was now at a stage where funding was being restored, so that may account for their relative optimism. In Quebec and New Brunswick cuts were also not too deep, and in the past few years funding has taken an upward swing (See Figures 12 and 15). BC's lack of optimism may be related to the overall state of its economy. It slipped badly in the 1980s and has fared even worse in the 1990s. Last year, the GDP was about $12 \%$ below the national average compared to $9 \%$ above in 1981 (Little, 2001).

The fourth factor expresses the belief that: in the future there will be more organizations working together in the voluntary sector and there will be more partnerships between corporate and nonprofit organizations. We called this the partnership factor. The mean score on this factor was above the midpoint of 6 , indicating general agreement that there will be more partnerships. There were no significant differences among provinces.

The fifth factor, which we called the management strategy factor, has three items which relate to the belief that in the future: more voluntary organizations will be involved in commercial ventures, there will be a greater focus on management control, marketing and entrepreneurship, and there will be a narrowing of focus towards serving their own constituents. The mean score on this factor (9.98) was above the scale midpoint of 9, indicating general agreement about the move toward more commercial and entrepreneurial behaviour. There were significant differences among provinces $(\mathrm{F}=4.074 ; \mathrm{df}=9,618 ; \mathrm{p}=.000)$ Quebec and PEI have a mean below the midpoint, indicating their lack of agreement that voluntary organizations will adopt more of a business focus in the future. The Quebec result is interesting given their agreement with impacts such as better use of staff skills, increased demands for accountability and addressing inefficiencies in Table 5. This seeming inconsistency in results for Quebec underlines the broad range of attitudes and actions encompassed under the term business or management and the impact of Quebec's strong union/socialist presence. Newfoundland had the highest mean on this index suggesting the viewed management strategy as important for the future of the voluntary sector. This attitude may be related to the economic turnaround that is transforming Newfoundland. As a result of corporate initiatives, from 1990 to 2000 the per capita GDP for Newfoundland rose 31\% compared to $18 \%$ in Canada. This stunning change has been fueled by the growth of the offshore oil industry that was introduced to replace fishing as the cornerstone of the economy (Little, 2001).

<Insert Table 10 here>

\section{Summary and Conclusions}

We began this paper by posing three questions for investigation. The first was to explore the perceptions, attitudes and actions of voluntary organizations in response to policy shifts. The data indicate that voluntary organizations are dissatisfied with the current environment. They see the gap between the haves and the have-nots expanding. Provincial governments are acting alone and not 
obtaining community support before making policy changes. Corporations are not making the voluntary sector a donating priority.

As a result of these environmental changes, organizations feel an increased demand for their services from client groups, more pressure to be accountable and provide measurable outcomes, and the need to make better use of staff skills. Overall, this has led to an increased sense of vulnerability. As responsibility for service delivery is downloaded, voluntary organizations are challenged to keep up with demand. At the same time funding cuts have reduced the range of options open to them to deal with the increased client-base.

In terms of specific actions, voluntary organizations have adopted a proactive approach. The most frequent responses have been to increase their focus on marketing activities and public relations, to work more closely with other organizations and to diversify their funding sources. The least likely responses are cost-cutting and efficiency measures; reducing staff and cutting back on services.

The current environmental situation also shapes the organizations' view of the future. They believe there will be more collaborations, more involvement in commercial ventures, more political action, more government control and more focus on management control, marketing and entrepreneurship. As a result, they feel the situation for marginalized groups in society will only get worse.

The second and third questions focus on the nature and reasons for inter-provincial differences in the attitudes and actions of voluntary organizations in response to external environmental challenges. The findings suggest that responses to the fiscal crisis have basically been similar across the country. However, economic history, cultural background and traditional relationships between the third sector and the government temper specific attitudes and actions.

Nova Scotia is one of the provinces that endured dramatic cuts to social expenditures. As a result, voluntary organizations in this province are the most dissatisfied with the shifts in public policy. They have felt these changes in their province through an increased demand for services, most likely as a result of having to cover the client base of organizations forced to close because of reduced funding. Despite increased investments in social programs (See Figures 11), negative attitudes about the future persist, influenced by other policies, such as salary freezes implemented to deal with the deficit. The Nova Scotia results illustrate the enduring impact of short-term drastic funding cuts to social programs on the long-term perception of voluntary organizations about their relationship with the government.

New Brunswick's voluntary organizations are the most optimistic of all provinces about the future. They are most likely to see the value of competition perhaps as a result of the success of McKenna's efforts to attract high tech industries (De Mont, 1994; Bemowski, 1994). In addition, social spending cuts in the province were never more than $5 \%$ in a given year, so organizations did not have to deal with the short-term drastic cuts that faced Nova Scotia's organizations (see Figure 12). The sector in New Brunswick is less likely than in other provinces to feel increased demands for accountability and collaboration. Perhaps because their funding has not been cut dramatically, they don't feel as vulnerable or undervalued by funders as other provinces.

As Canada's smallest province, Prince Edward Island is less likely to report an increased demand for 
services or a need to cover off the services for other organizations. As a result of fiscal constraints, actions taken by voluntary organizations to adapt to funding changes have not included businessfocused solutions. PEI's organizations are lower than other provinces on business orientation, embracing revenue diversification as a priority and seeing a role for management strategies in the future of the sector. It is understandable that corporate culture is not a significant part of the Island's persona given its resource and tourism-based economy. Although funding in 1999 was still 10\% below 1993 levels (see Figure 13), organizations felt less vulnerable than those in other provinces. As yearly decreases were less than 5\%, there may have been no impact on organizational attitudes or structures, because the reductions were too small to necessitate significant operational changes.

The attitudes and actions of voluntary organizations in Newfoundland reflect the economic history of the province. Because of limited opportunities, this province has not been a destination of choice for inter-provincial migration (Little, 2001). Likewise the per capita investment in social expenditures has been much higher than in other provinces in part in response to the high unemployment rate and the seasonal nature of employment (see Figure 4). Organizations were less likely than those in other provinces to feel an increased demand for services, but also most likely to feel forced to amalgamate. The sector is also more positively disposed to the benefits of competition and management strategies and practices, perhaps because they are seeing the economic benefits of corporate investment in the province through development of off-shore oil. Premier Tobin's policies reflect the desire to be fiscally prudent with selective budget cuts, while still maintaining the social safety net through investment in health and education. While Newfoundland's voluntary sector shares the concerns of organizations in other provinces about devolution and funding cuts, they are less pessimistic and more optimistic about its prospects for the future than are some other provinces.

Quebec's social expenditures were on a steady decline from 1994 to 1998, but in 1999 it increased to the level of 1996 investment (see Figure 15). Although Quebec has a diversified economy with a significant corporate presence, voluntary organizations do not report seeing business practices as the solution for dealing with devolution and funding cuts. This province's organizations were less likely to see the value of either competition or management strategies for the sector. These attitudes may have been influenced by the nationalist culture of the province where adopting a business orientation may be linked to buying into the values of English Canada and the strong culture of labour unionism and socialist principles that were embraced during and after the Quiet Revolution of 1960.. In the beginning, Quebec had a Stage IV (direct government funding) structure for social spending. The lack of interest of the voluntary sector in emulating corporate practices may reflect the historical relationship of the sector to the government.

The consensus among the voluntary organizations in Ontario is that the sector has had a very difficult time functioning in the current political environment and that recent policy changes are not short term aberrations, but rather a fundamental redefinition of the relationship between the sector and the government. Because government policy seems more directed toward tax cuts and downloading social service responsibilities, organizations in Ontario scored highest on pessimism and lowest on optimism about the future. In addition, these same organizations had some of the lowest levels of satisfaction with the state of the external environment, felt very vulnerable, and believed they were not a priority among funders. This negative atmosphere is the product of dramatic cuts to social expenditures in a very short time period, and this lower level of support's becoming the new baseline (see Figure 16). Not only was the policy direction a departure from 
previous governments, but also the style of governing concentrated power in the hands of a few. Major changes could be made in delivery systems for government services without any community input. To deal with the new fiscal environment, more so than other provinces, Ontario adopted a business orientation, recognized the value of competition, and engaged in collaborative activities with other organizations. Choosing a business solution is consistent with the corporate economy and values of this province. Because Ontario is Canada's most populous and economically important province, with the highest public relations profile, policies enacted locally can have attitudinal repercussions across the country. The negative relationship between the Ontario government and the voluntary sector may have affected the perception of those in other provinces about government support for the social safety net, even in those where cuts have not been as severe.

Although Manitoba shares the lowest spot on the optimism scale with Ontario, there are few other similarities in either attitudes or actions between these two neighbouring provinces. Manitoba's social spending was neither reduced as dramatically nor to the same extent as Ontario's (see Figures 16 and 17). The Tories and New Democrats take turns governing but regardless of the party in power, most policy initiatives continue to reflect the importance of social welfare to the culture of Manitoba. This illustrates the importance of tradition in tempering responses to external environmental challenge.

Saskatchewan is the only province to experience insignificant or no cuts to social welfare expenditures during the 1990s (see Figure 18). Given this stable funding, it is not surprising that among all provinces, voluntary organizations in Saskatchewan are the most satisfied with the current environment and the least pessimistic about the future. This province's culture puts such a high value on maintaining the social safety net, that even in the face of burgeoning deficits, spending increased in social welfare (Dyck, 1996).

With the election of Ralph Klein, Alberta embarked on programs of cost-cutting and restructuring that resulted in dramatic cuts in social expenditures (see Figure 19). As a result, Alberta was the province whose voluntary organizations were most likely to feel an increased demand for services. These same organizations have adopted a business orientation and revenue generation strategies as the way to deal with the new funding model. What is interesting about Alberta is that its organizations are not as strongly pessimistic about the future as Ontario organizations even though they experienced similarly drastic cuts in social expenditures. With Alberta's more volatile resource-based economy, its third sector may be more experienced than Ontario's in dealing with dramatic upturns and downturns in prosperity. Attitudes about and actions taken as a result of a fiscal crisis, thus, may be tempered by provincial historical experience.

British Columbia has had small decreases in social funding every year (see Figure 20). Only in propensity to adopt a business orientation is B.C. higher than most other provinces. This finding reflects the importance placed on business solutions in a province with a large corporate and entrepreneurial presence. Despite the fact that BC suffered less severe cuts than other provinces, it shares their feelings of pessimism about the future. This suggests that cumulative cuts over a series of years, even if the cuts are small, may promote negative attitudes.

Although the devolution and funding cut experience across the provinces varies from dramatic to not at all, the negative evaluation of the environment and the concerns about the relationship between 
the government and the voluntary sector are consistent across the country. The general level of pessimism may be a reflection of the policies and programs of the federal government. Transfer payments were reduced, and CAP was eliminated. Undoubtedly, this has had an impact of the perception of voluntary organizations about their role in Canada and has contributed to the fiscal challenges of individual organizations. Adding to this negative atmosphere for the voluntary sector has been the constant media focus on the "hard right turn" of Canadian politics. It focuses on balanced budgets, deficit elimination, debt reduction, smaller government, and the elevation of business practices as the gold standard for success and economic viability. All provinces share a similar concern about the impact of policy shifts on the sector. However, the extent of dissatisfaction and the level of pessimism about the future, as well as the propensity to adopt business practices as a solution are tempered by provincial policies and programs including the nature of the cuts endured to date, the traditional relationship between the sector and the provincial government, the cultural background of the province and the economic history of the region.

\section{References}

Bailey, Ian. 1998. Premier prepared to boost economy: won't compromise key values. Canadian Press Newswire, January 29.

Baker, J. 1996. Metro Toronto Social Planning Council. Personal Communication

Banting, K. 1987. Visions of the Welfare State. In Seward, S.B. (Ed). The Future of Social Welfare Systems in Canada and the United Kingdom. Halifax: Institute for Research on Public Policy.

Beack, M. 1985. Politics of Nova Scotia. Tantallon, N.S. : Four East Publications

Bemowski, K. 1994. Canadian premier works to improve constituents' quality of life. Quality Progress, Oct. 1994, v27, n10, p35(4).

Blaney, E. \& McFarland, N. 1992. The Self Help Illusion: 'Community Voluntary Action' and the Decline of Social Services in New Brunswick. In McKay, I. \& Milsom, S.(Eds.) Towards a New Maritimes. City: Publisher.

Boase, J.P. 1996. Trends in social policy: Towards the millennium. In Dunn, C. (Ed.) Provinces: Canadian provincial politics. Peterborough, ON: Broadview Press.

Bracken D.C. \& Hudson, P. 1988. Manitoba. In Ismail, J.S. \& Vaillancourt, Y. (Eds.) Privatization and Provincial Social Services in Canada: Policy, Administration and Delivery. Edmonton: University of Alberta Press.

Brezanson, K. 1998 Act in haste: The style, scope and speed of change in Ontario. Ottawa : Caledon Institute of Social Policy.

Brown, L.A., Roberts, J.K. \& Warnock, J.W. 1999. Saskatchewan Politics from Left to Right 44- 
99. Regina: Hinterland Publications.

Browne, P.L. (1996). Love in a cold world? The voluntary sector in the age of cuts. Ottawa: Canadian Centre for Policy Alternatives.

Burge, I. 1992. Fighting Back: The Struggle for Social Assistance on the Island. In McKay, I. \& Milson, S. (Eds.) Towards a New Maritimes. City: Publisher.

Burson, G. 2001. Pre-revolutionary Europe (c. 1715-1789). (click here) Accessed July

$11,2001$.

Callahan, M. \& McNiven, C. 1988. British Columbia. In Ismail, J.S. \& Vaillancourt, Y. (Eds.) Privatization and Provincial Social Services in Canada: Policy, Administration and Delivery. Edmonton: University of Alberta Press.

Caldardo, C. 1979. Society and Politics in Alberta. Agincourt, ON: Methuen.

Cassidy, H.M. 1945. Public Health and Welfare Reorganization. Toronto: Ryerson Press.

Chandler, M.A \& Chandler, W.M. 1979. Public Policy and Provincial Politics. Toronto: McGrawHill Ryerson.

Clague, M., Dill, R., Seebaran, R. \& Wharf, B. 1984. Reforming human services: The experience of the community resource boards in B.C. Vancouver: UBC Press.

Clancy, P., Bickerton, J., Haddow, R \& Stewart I. 2000. The Savage Years: The Perils of Reinventing Government in Nova Scotia. City: Publisher.

Cox, Wendy. 1999. NDP bucks trend with hefty deficit, spends on health, education. Canadian Press Newswire, March 30.

DeMont J. 1991. Home for the Hero. Macleans's, December 9, 1991, v104, n49, p18.

DeMont J. 1994. Fast Frank: How New Brunswick's premier turned his province into Canada's social laboratory. Maclean's, April 11, 1994, v107, n15, p22(6).

Drache, D. The eye if the hurricane: Globalization and social policy reform. In Drache, D. (Ed.) Warm Heart, Cold Country: Fiscal and Social Policy Reform in Canada. Ottawa: Caledon Institute and Renouf Publishing.

Dyck, R. 1996. Provincial Politics in Canada: Towards the Turn of the Century, $3^{\text {rd }}$ Edition. Scarborough, ON: Prentice-Hall Canada.

Eager, E. 1980. Saskatchewan Government: Politics and Pragmatism. Saskatoon: Western Producer Prairie Books. Date could be wrong because refers to things after 1980 
Education Resources. 2000. Key Dates in Poor Law and Relief: Great Britain 1300 - 1899. http://www.netcentral.co.uk/steveb/dates/poor.htm. Accessed July 11, 2001.

Eisler, D. 1987. Rumours of Glory: Saskatchewan and the Thatcher Years. Edmonton: Hurtig Publishers.

Evans, B. and Shields, J. 1998. Reinventing the State: Public Administration 'Reform' in Canada. Halifax: Fernwood Publishing.

Ferguson, D. 1997 Literacy in your own backyard: The challenge in New Brunswick. In Ford, R. \& Zussman, D (Eds.) Alternative service delivery: Sharing governance in Canada. Toronto : Institute of Public Administration of Canada

Forbes, E. 1985. New Brunswick. In The Canadian Encyclopedia, Volume II. Edmonton: Hurtig Publishers.

Foster, M.K. \& Meinhard, A.G. (2000). Strategic responses of voluntary social service organizations to funding changes: The Ontario situation. Paper presented at the annual Academy of Management Conference, Toronto, ON.

Friesen, G. 1996. River Road: Essays on Manitoba and Prairie History. Winnipeg: University of Manitoba Press.

Friesen, G. 1999. The West: Regional Ambitions, National Debates, Global Age. Toronto: Penguin.

Godfrey, S. R. 1985. Human Rights and Social Policy in Newfoundland 1832-1982: Search for a Just Society. City: Publisher

Government of Alberta, 2001a. http://www.gov.ab.ca/aboutalberta/history_settlement.cfm. Accessed July 15, 2001.

Government of Alberta, 2001b.http://www.assembly.ab.ca/lao/library/premiers/brownlee.htm. Accessed July 15, 2001.

Government of Manitoba, 2001._Http://www.gov.mb.ca. Accessed July 16, 2001.

Government of Prince Edward Island, 2001. http://www.gov.pe.ca/law/index.php3. Accessed July 20, 2001.

Graham, B. \& Lightman, E. The Crunch: Financing Ontario's Social Programs. Toronto: Premier's Council on Health, Well-being and Social Justice.

Greenwood, R. 1995. Newfoundland: Between colonial paternalism and self-sufficiency. North Atlantic Islands Program at http://www.upei.ca/ iis/naip/newfound.htm. Accessed July 20, 2001. 
Guest, Dennis. 1997. The emergence of social security in Canada. $3^{\text {rd }}$ edition. Vancouver : UBC Press.

Gwynn, R. 1972. Smallwood: The unlikely revolutionary. Toronto: McClelland and Stewart Hall, M. \& Banting, K.G. (2000). The nonprofit sector in Canada: an introduction. In K.G. Banting (Ed.), The nonprofit sector in Canada. Montreal and Kingston: School of Policy Studies, Queen's University.

Hepworth, H.P. 1985. Trends in provincial social service expenditures: 1963 - 1982. In Ismael, J. (Ed.), Canadian Social Welfare Policy: Federal and Provincial Dimensions. Kingston: McGillQueens University Press.

Hesketh, B. 1997. Major Douglas and Alberta Social Credit. Toronto: University of Toronto Press.

Hornick, J.P., Thomlison, R.J. \& Nesbitt, L. 1988. Alberta. In Ismail, J.S. \& Vaillancourt, Y. (Eds.) Privatization and Provincial Social Services in Canada: Policy, Administration and Delivery. Edmonton: University of Alberta Press.

Hostland, D. 1995. Structural unemployment in Canada: Some Stylized Facts. http://www.hrdcdrhc.gc.ca/arb/publications/research/r-96-1e.pdf. Accessed June 11, 2001.

House, J. D. 1999. Against the tide: Battling for economic renewal in Newfoundland and Labrador. Toronto : University of Toronto Press.

Ismail, J.S. 1988. Privatization of social services: A heuristic approach. In Ismail, J.S. \& Vaillancourt, Y. (Eds.) Privatization and Provincial Social Services in Canada: Policy, Administration and Delivery. Edmonton: University of Alberta Press.

Jeffrey, B. 1999. Hard right turn: The new face of neo-conservatism in Canada. Toronto: Harper Collins Canada.

Jensen, J. \& Phillips, S.D. 2000. Distinctive Trajectories: Homecare and the Voluntary Sector in Quebec and Ontario. In K.G. Banting (Ed.), The nonprofit sector in Canada. Montreal and Kingston: School of Policy Studies, Queen's University.

Johnson, A. 1987. Social policy in Canada: The past as it conditions the present. In Seward, S.B. (Ed). The Future of Social Welfare Systems in Canada and the United Kingdom. Halifax: Institute for Research on Public Policy.

Johnson, A.F., McBride, S. and Smith, P.J. 1994. Introduction. In Johnson, A.F., McBride, S. and Smith, P.J. (Eds.) Continuities and Discontinuities: The Political Economy of Social Welfare and Labour Market Policy in Canada. Toronto: University of Toronto Press.

Johnson, N. 1987. The Welfare State in Transition. London: Wheatsheaf Books. 
Kimberley J. 1981. Initiation, Innovation and Institutionalization in the Creation Process. In Kimberley J. and Miles, R. (Eds.), The Organizational Life Cycle. San Francisco: Jossey-Bass.

Lang, V. 1974. The service state emerges in Ontario. Toronto: Ontario Economic Council.

Little, B. 2001. Gap Shrinking Between B.C., Newfoundland, The Globe and Mail, August 21, B8.

MacGregor, J.G. 1981. A History of Alberta. Edmonton: Hurtig.

Martin, S. 1985. An Essential Grace: Funding Canada's Health Care, Education, Welfare, Religion and Culture. Toronto: McClelland and Stewart.

MacKay, R.A. 1946. Newfoundland. Toronto: Oxford University Press.

Mishra, R., Laws, G. and Harding, P. 1988. Ontario. In Ismail, J.S. \& Vaillancourt, Y. (Eds.) Privatization and Provincial Social Services in Canada: Policy, Administration and Delivery. Edmonton: University of Alberta Press.

McAllister, J. A. 1984. The Government of Edward Shreyer. Montreal \& Kingston: McGillQueens University Press.

McBride, S. \& Shields, J. (1997). Dismantling a nation: The transition to corporate rule in Canada. Halifax: Fernwood Publishing.

McLeod, C. 1998. Government moves threaten health of PEI boards: Members fear unexpected firing marks beginning of the end for regional authority. Medical Post, 1998, v.34(7) P. 60.

McNiven, C. 1996. Horizontal integration and the development of the welfare state. In Tester, F.J., McNiven, C. and Case, R. (Eds.) Critical Choices, Turbulent Times. Vancouver: UBC.

McRoberts, K. 1993 Quebec: Social Change and Political Crisis. $3^{\text {rd }}$ Edition. Toronto : McClelland \& Stewart.

Meinhard, A.G. \& Foster, M.K. 1997. Responses of Women's Voluntary Organizations to the Changing Social, Political and Economic Environment. CVSS Working Paper \#8, Toronto: Ryerson University.

Meinhard, A.G. \& Foster, M.K. 2000. Third Sector Strategic Responses to Canada's Changing Social, Political and Economic Climate: A Comparative Analysis, Presented at the Fourth International Conference of the International Society for Third Sector Research, Dublin, Ireland.

Moscovitch, A. 1997. Social assistance in Ontario. In Ralph, D. S., Regimbald, A. \& St. Armand, N. (Eds.) Open for Business, Closed to People: Mike Harris's Ontario. Halifax: Fernwood Publishing. 
Mullaly, R. \& St. Amand, M. 1988. New Brunswick. In Ismail, J.S. \& Vaillancourt, Y. (Eds.) Privatization and Provincial Social Services in Canada: Policy, Administration and Delivery. Edmonton: University of Alberta Press.

Nikiforuk, A., Pratt,. \& Wanagas, D. 1987. Running on Empty: Alberta After the Boom. Edmonton : NeWest Press.

Panitch, L. 1994. Changing Gears: Democratizing the Welfare State. In Johnson, A.F., McBride, S. and Smith, P.J. (Eds.) Continuities and Discontinuities: The Political Economy of Social Welfare and Labour Market Policy in Canada. Toronto: University of Toronto Press.

Peterson, T. 1978. Manitoba: Ethnic and class politics. In Robin, M. (Ed.) Canadian Provincial Politics: The party systems of the ten provinces. Scarborough: Prentice-Hall Canada.

Phillips, P. 1990. Manitoba in the agrarian period: 1870-1940. In Silver, J. \& Hull, J. (Eds). The Political Economy of Manitoba. Canadian Plains Research Centre: University of Manitoba.

Pitsula, J. M. \& Rasmussen, K. 1990. Privatizing a Province: The New Right in Saskatchewan. Vancouver: New Star Books.

Prince, M.J. 1996. At the Edge of Canada's Welfare State: Social Policy Making in British Columbia. In Carty, R.C. (Ed.) Politics, Policy, and Government in British Columbia. Vancouver: UBC Press

Reckert, J. 1993. Public Funds, Private Provision: The Role of the Voluntary Sector. Vancouver: University of British Columbia Press.

Resnick, P. 1994. Neo-conservatism and beyond. In Johnson, A.F., McBride, S. and Smith, P.J. (Eds.) Continuities and Discontinuities: The Political Economy of Social Welfare and Labour Market Policy in Canada. Toronto: University of Toronto Press.

Rice, J. J. \& Prince, M. J. 2000. Changing Politics of Canadian Social Policy. Toronto: University of Toronto Press.

Riches, G. \& Harding, J. 1995. Economic Growth and Social Spending in Saskatchewan 1971 82: Some Missing Questions. In Harding, J. (Ed). Social Policy and Social Justice: The NDP government in Saskatchewan during the Blakeney Years. Waterloo: Wilfrid Laurier University Press.

Riordan, S. (2000). Put your money where your mouth is!: The need for public investment in women's organizations. Gender and Development, 8(1), 63-69.

Robb, A \& Holman, H.T. 1985. Prince Edward Island. In The Canadian Encyclopedia, Volume III. Edmonton: Hurtig Publishers. 
Salamon, L.M. 1995. Partners in Public Service: Government-Nonprofit Relations in the Modern Welfare State. Baltimore: The Johns Hopkins University Press.

Savoie, D.J. \& Beaudin, M. 1994. Public Sector Adjustments and the Maritime Provinces. In Benedetti, G. J. \& Lamarche, R. H. (Eds.) Shock Waves: The Maritime Urban System in the New Economy. City: Publisher.

Scarfe, B. 1996. Public Finance and Fiscal Policy in British Columbia. In Carty, R.C. (Ed.) Politics, Policy, and Government in British Columbia. Vancouver: UBC Press

Scott, J.T. (1992). Voluntary sector in crisis: Canada's changing public philosophy of the state and its impact on voluntary charitable organizations. Ann Arbor: University Microfilms.

Secrétariat aux Affaires intergouvernementales canadiennes. 1998. Quebec's Historical Position on the Federal Spending Power: 1944-1998. cex.gouv.qc.ca/saic/english Accessed July 10, 2001.

Senior Citizen's Secretariat, Nova Scotia. 1996. Poverty, Poor Houses and Private Philanthropy. 
Shedd, M.S. 1997. Family and Social Services: The Alberta Deficit Elimination Program and Welfare Reform. In Bruce, C., Kneebone, R. \& McKenzie, K. A government reinvented: A study of Alberta's deficit elimination program. City: Publisher.

Silverstein, S. 1968. The Rise, Ascendancy, and Decline of the Cooperative Commonwealth Federation Party in Saskatchewan, Canada. Unpublished Doctoral Dissertation, Washington University. 1968.

Sinclair, S. 1994. Atlantic Economic Cooperation. Ottawa, Ont. : Canadian Centre for Policy Alternatives.

Smardon, B. 1991. The federal welfare state and the politics of retrenchment in Canada. Journal of Canadian Studies, 26(2), 122-141. Reprinted in Blake, R. \& Keshen, J. (Eds.) Social Welfare Policy in Canada: Historical Readings. Toronto: Copp Clark Ltd. 1995.

Smith, D. E. 1974. Prairie Liberalism: The Liberal Party in Saskatchewan 1905-1971. Toronto: University of Toronto Press.

Social Planning Council of Metro Toronto. Caring for Profit: The Commercialization of Human Services in Ontario. Toronto: The Council, 1984.

Struthers, J. 1994. The limits of affluence: Welfare in Ontario, 1920-1970. Toronto: University of Toronto Press.

Summers, W.F. 1985. Newfoundland. In The Canadian Encyclopedia, Volume II. Edmonton: Hurtig Publishers.

Tester, F.J. 1996. One piece at a time: Pragmatic politics and the demise of Canadian Welfarism. In Tester, F.J., McNiven, C. and Case, R. (Eds.) Critical Choices, Turbulent Times. Vancouver: UBC.

Torjman, S. 1996. Milestone or millstone? The legacy of social security review. In Tester, F.J., McNiven, C. and Case, R. (Eds.) Critical Choices, Turbulent Times. Vancouver: UBC Press.

Tucker, D.J., Singh, J.V. \& Meinhard, A.G. (1990). Organizational form, population dynamics and institutional change: A study of birth patterns of voluntary organizations. Academy of Management Journal, 33, 151-178.

Valliancourt, Y. 1988. Quebec. In Ismail, J.S. \& Vaillancourt, Y. (Eds.) Privatization and Provincial Social Services in Canada: Policy, Administration and Delivery. Edmonton: University of Alberta Press.

Van Til, John. 1988. Mapping the third sector: Voluntarism in a changing social economy. New York: Foundation Center. 
Wallace, E. 1950. The origin of the social welfare state in Canada, 1867-1900. Canadian Journal of Economics and Political Science, 16 (3), 383-393. Reprinted in Blake, R. \& Keshen, J. (Eds.) Social Welfare Policy in Canada: Historical Readings. Toronto: Copp Clark Ltd. 1995.

White, D. 1997. Quebec state and society. In Fournier, M., Rosenberg, M. and White, D. (Eds.) Quebec Society: Critical Issues. City: Publisher. 
Figure 1: Nova Scotia Social Expenditure Per-Capita

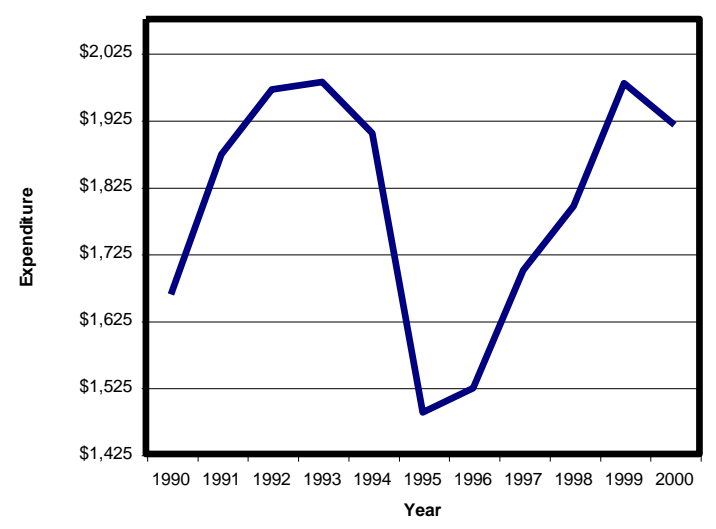

Figure 2: New Brunswick Social Expenditure Per-Capita

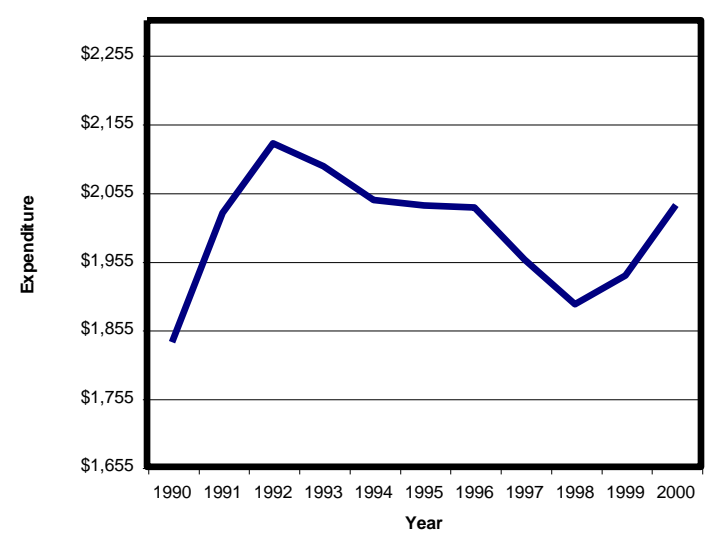


Figure 3: P.E.I. Social Expenditure Per-Capita

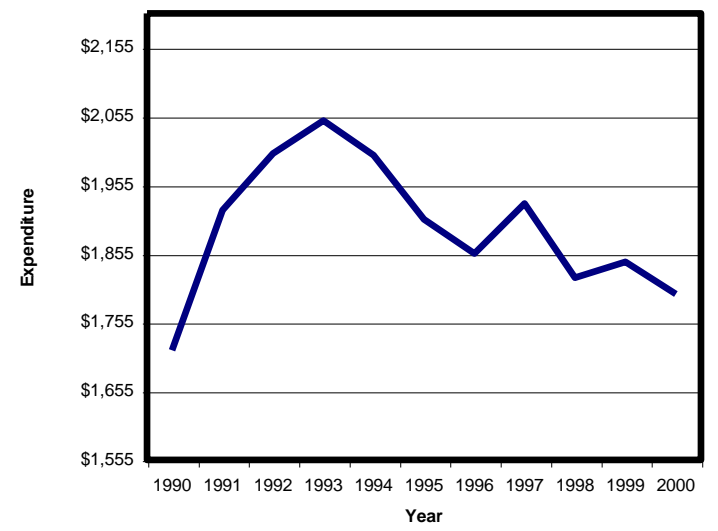

Figure 4: Newfoundland Social Expenditure Per-Capita

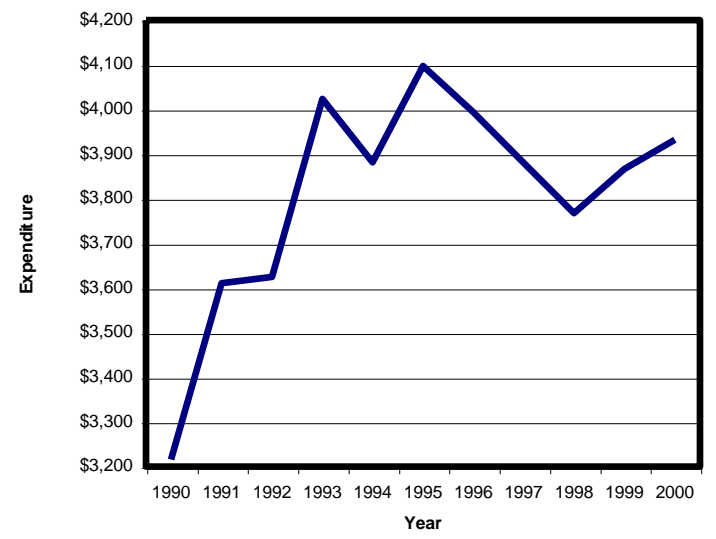


Figure 5: Quebec Social Expenditure Per-Capita

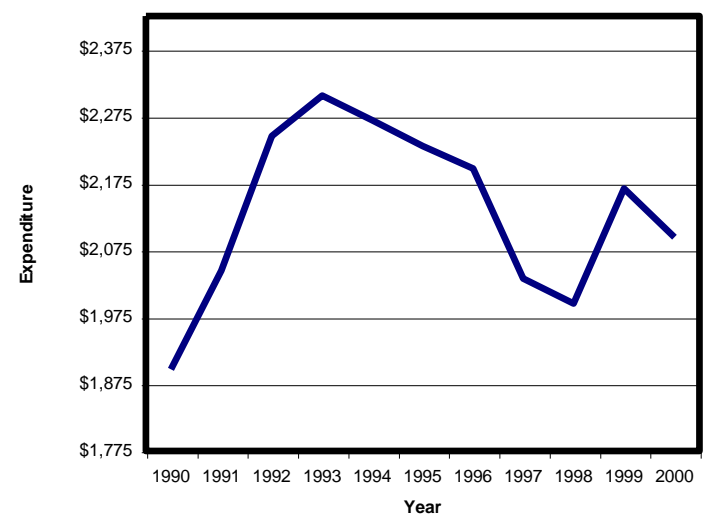

Figure 6: Ontario Social Expenditure Per-Capita

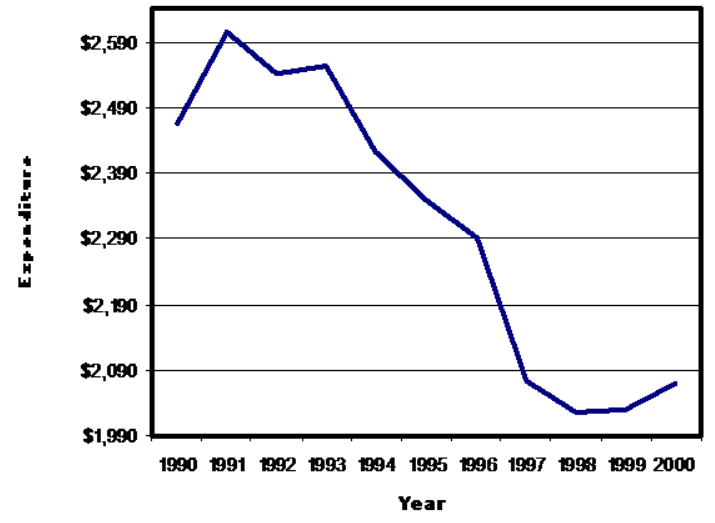


Figure 7: Manitoba Social Expenditure Per-Capita

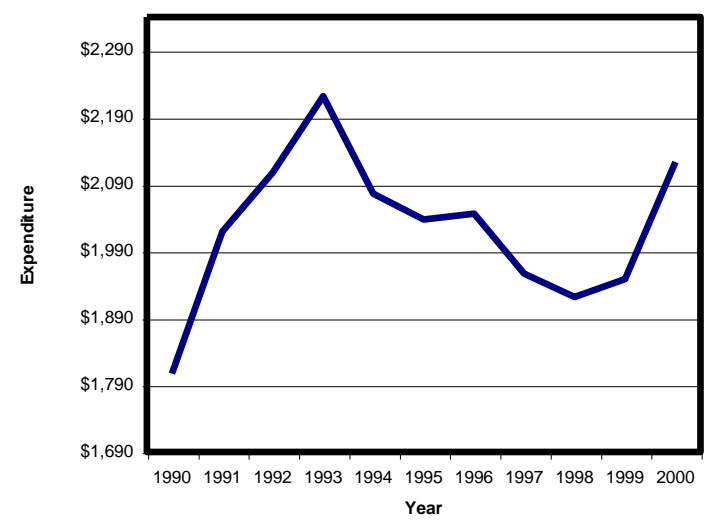

Figure 8: Saskatchewan Social Expenditure Per-Capita

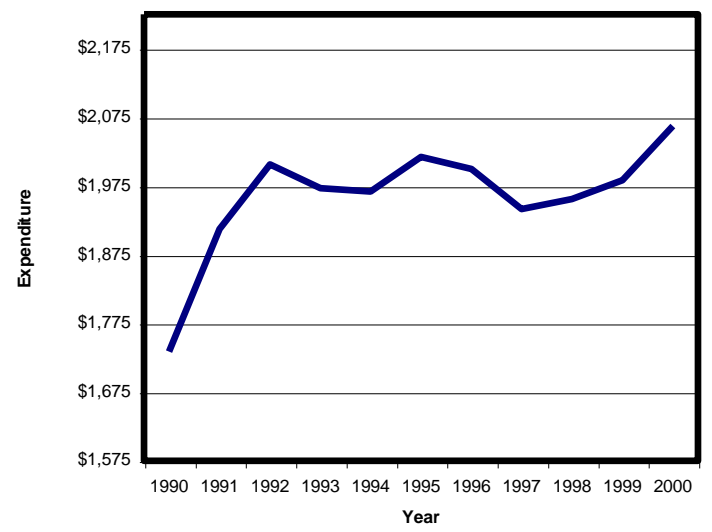


Figure 9: Alberta Social Expenditure Per-Capita

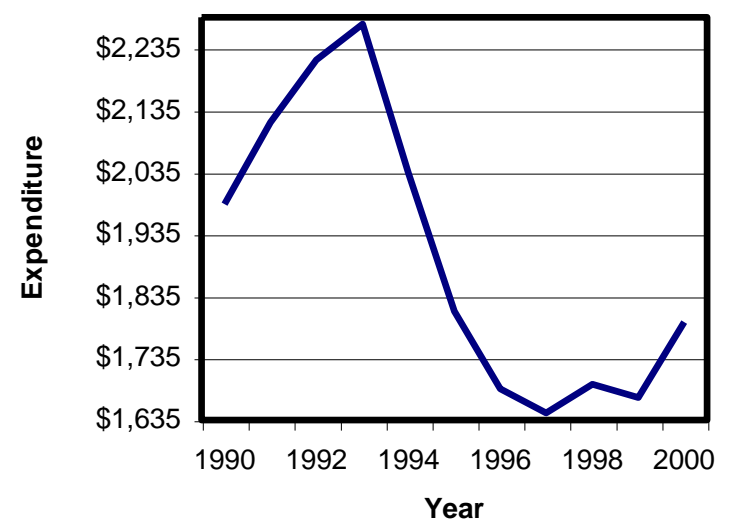

Figure 10: British Columbia Social Expenditure Per-Capita

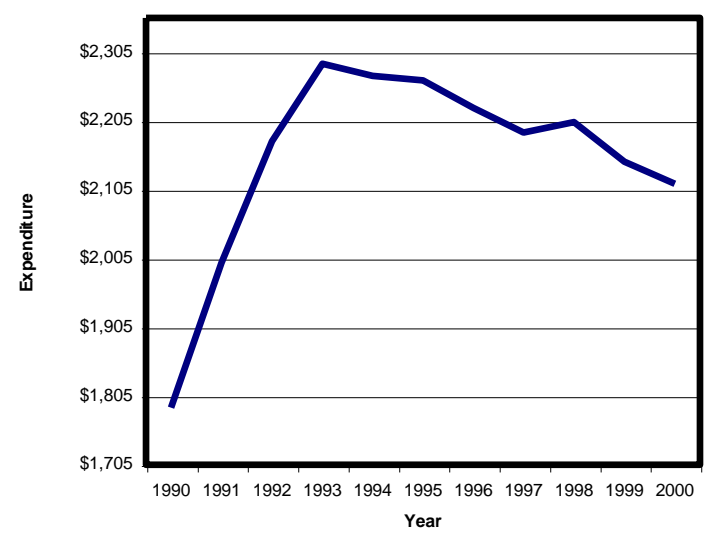


Figure 11: Nova Scotia Social Expenditure Percentage Change from 1993 (per-capita)

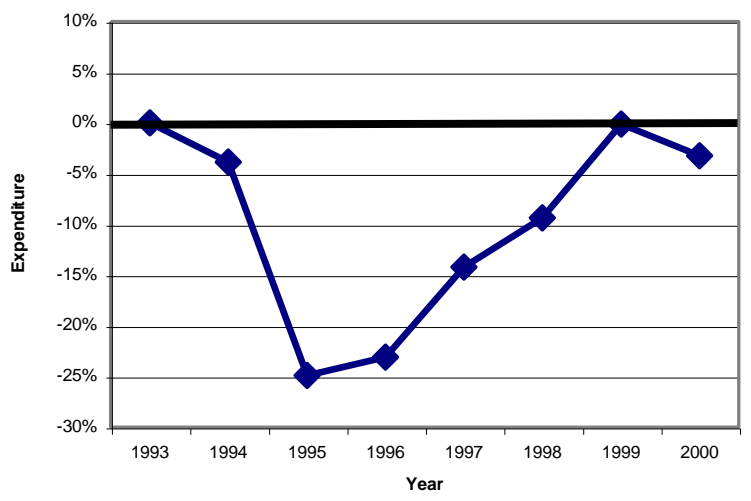

Figure 12: New Brunswick Social Expenditure Percentage Change from 1993 (percapita)

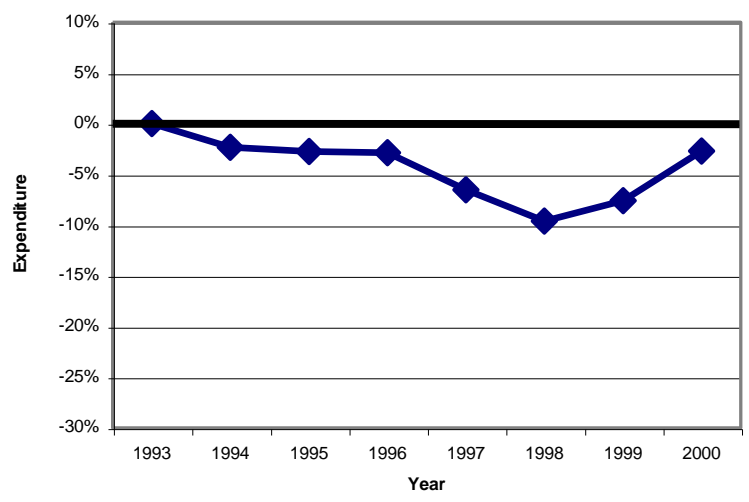


Figure 13: P.E.I Social Expenditure Percentage Change from 1993 (per-capita)

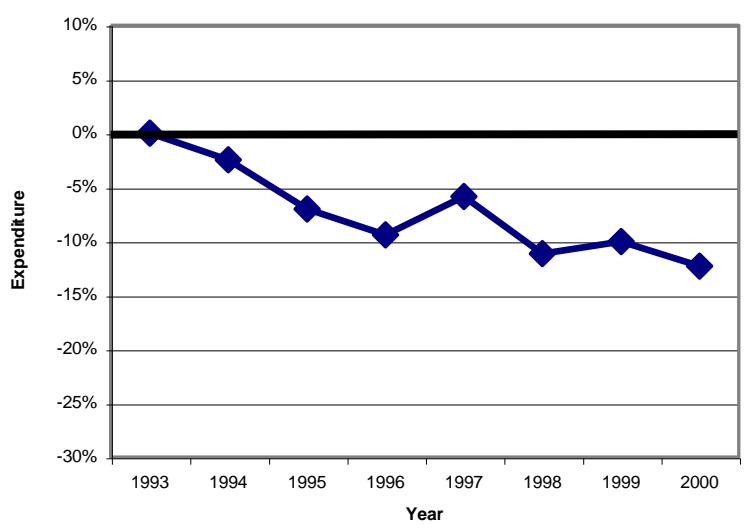

Figure 14: Newfoundland Social Expenditure Percentage Change from 1993 (per-capita)

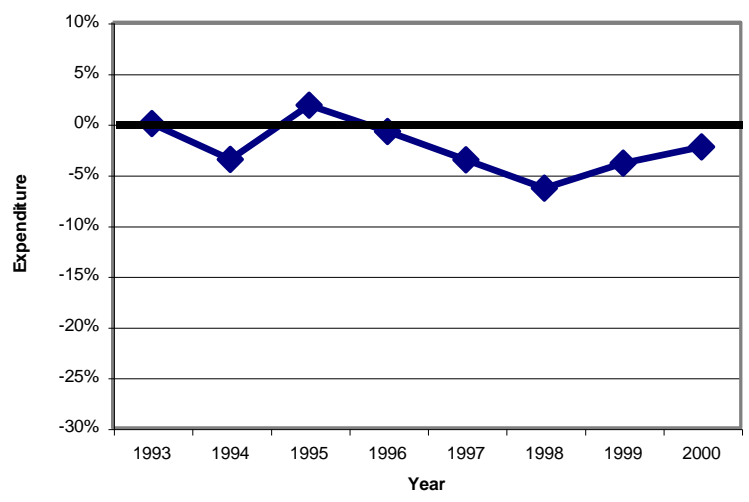


Figure 15: Quebec Social Expenditure Percentage Change from 1993 (per-capita)

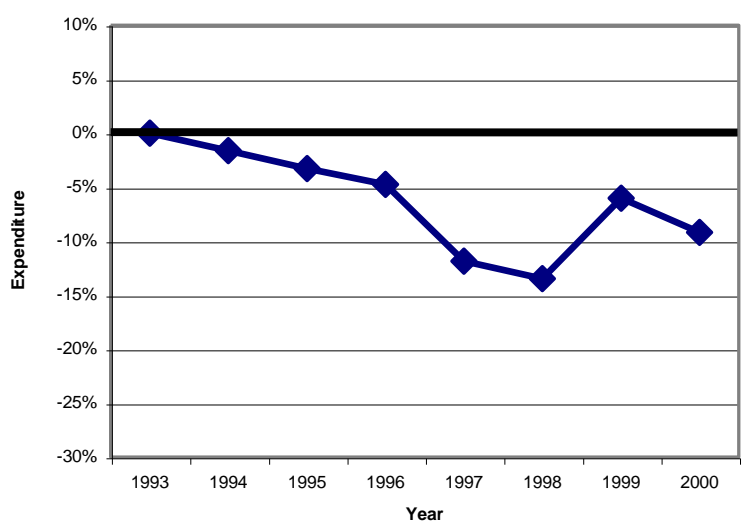

Figure 16: Ontario Social Expenditure Percentage Change from 1993 (per-capita)

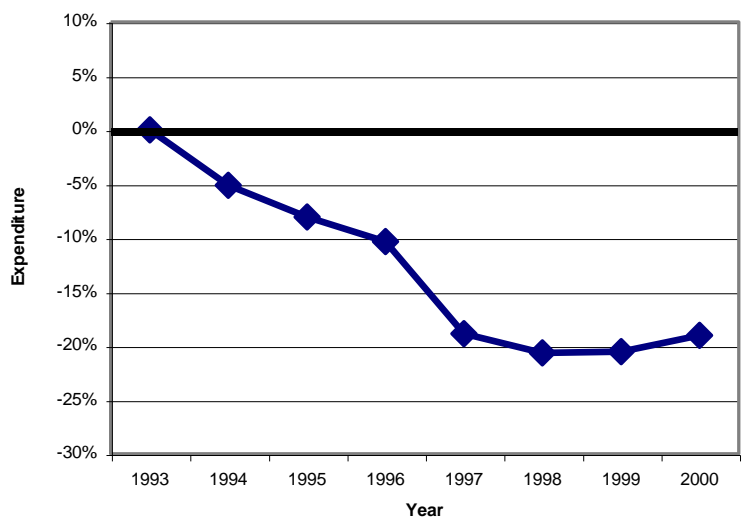


Figure 17: Manitoba Social Expenditure Percentage Change from 1993 (per-capita)

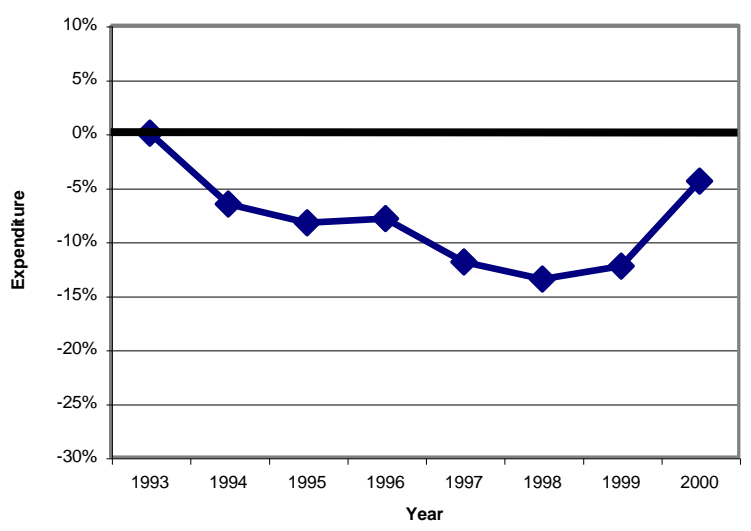

Figure 18: Saskatchewan Social Expenditure Percentage Change from 1993 (percapita)

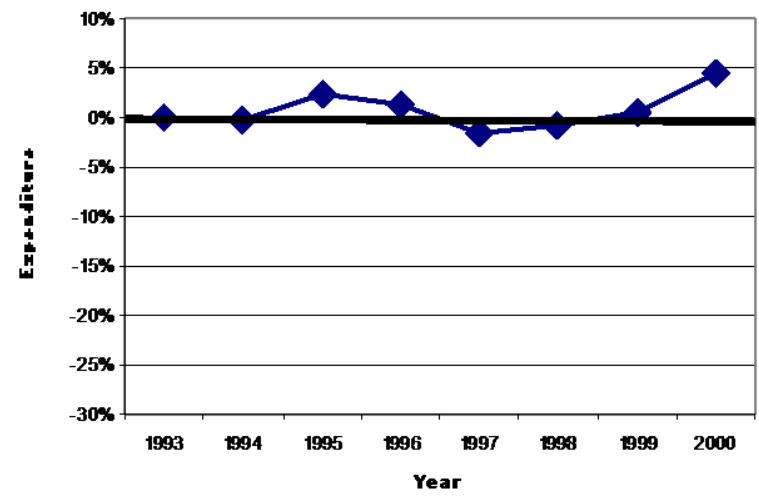


Figure 19: Alberta Social Expenditure Percentage Change from 1993 (per-capita)

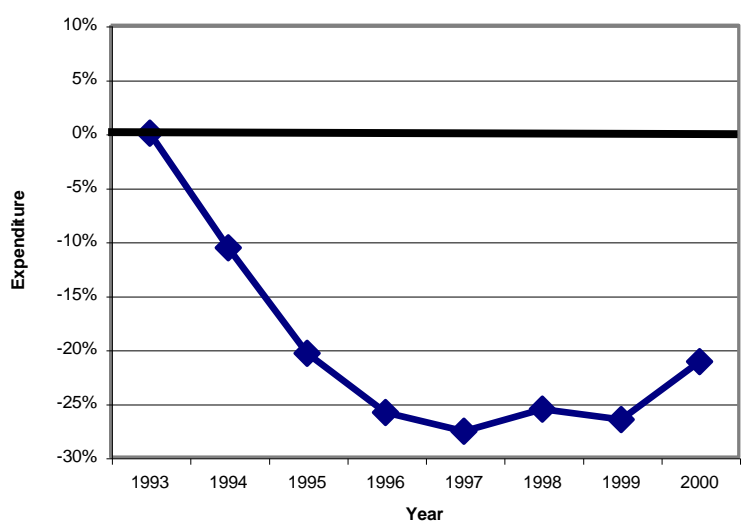

Figure 20: British Columbia Social Expenditure Percentage Change from 1993 (percapita)

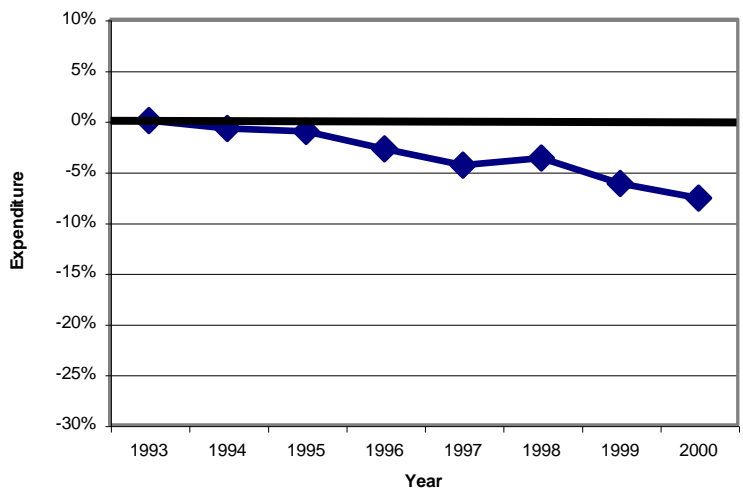


Table 1: Sample Distribution by Province

\begin{tabular}{|l|c|c|}
\hline Province & Sample Size & Percent of Total Sample \\
\hline British Columbia & 82 & 13 \\
\hline Alberta & 45 & 7 \\
\hline Saskatchewan & 44 & 7 \\
\hline Manitoba & 33 & 5 \\
\hline Ontario & 182 & 28 \\
\hline Quebec & 116 & 18 \\
\hline New Brunswick & 47 & 7 \\
\hline Prince Edward Island & 26 & 4 \\
\hline Nova Scotia & 45 & 7 \\
\hline Newfoundland & 25 & 4 \\
\hline TOTAL & 645 & 100 \\
\hline
\end{tabular}

Table 2: Provincial Sample by Organizational Size

\begin{tabular}{|l|c|c|c|c|}
\hline Province & Sample Size & \% Small & \% Medium & \% Large \\
\hline British Columbia & 82 & 20 & 60 & 21 \\
\hline Alberta & 45 & 24 & 58 & 18 \\
\hline Saskatchewan & 44 & 32 & 54 & 14 \\
\hline Manitoba & 33 & 21 & 67 & 12 \\
\hline Ontario & 182 & 19 & 50 & 31 \\
\hline Quebec & 116 & 22 & 63 & 15 \\
\hline New Brunswick & 47 & 38 & 49 & 13 \\
\hline Prince Edward Island & 26 & 58 & 38 & 4 \\
\hline Nova Scotia & 45 & 31 & 51 & 18 \\
\hline Newfoundland & 25 & 52 & 36 & 12 \\
\hline TOTAL & 645 & 26 & 54 & 20 \\
\hline
\end{tabular}

Table 3: Provincial Sample by Organizational Mandate

\begin{tabular}{|l|c|c|c|c|}
\hline Province & Sample Size & $\begin{array}{c}\text { \% Social } \\
\text { Services }\end{array}$ & \% Health & $\begin{array}{c}\text { \% Education } \\
\text { or Advocacy }\end{array}$ \\
\hline British Columbia & 82 & 55 & 15 & 30 \\
\hline Alberta & 45 & 58 & 13 & 29 \\
\hline Saskatchewan & 44 & 36 & 20 & 43 \\
\hline Manitoba & 33 & 49 & 21 & 30 \\
\hline Ontario & 182 & 57 & 22 & 20 \\
\hline Quebec & 116 & 57 & 15 & 28 \\
\hline New Brunswick & 47 & 49 & 19 & 32 \\
\hline Prince Edward Island & 26 & 58 & 15 & 27 \\
\hline Nova Scotia & 45 & 53 & 18 & 29 \\
\hline Newfoundland & 25 & 48 & 16 & 36 \\
\hline TOTAL & 645 & 54 & 18 & 28 \\
\hline
\end{tabular}


Table 4. Perceptions of the Environment: Mean scores for the total sample and each province*

\begin{tabular}{|c|c|c|c|c|c|c|c|c|c|c|c|c|c|c|}
\hline Statements About the Environment & Total & $\mathrm{BC}$ & $\mathrm{AB}$ & SK & $\mathrm{MN}$ & $\mathrm{ON}$ & QB & NB & $\mathrm{PE}$ & NS & $\mathrm{NF}$ & $\mathrm{F}$ & Df & $\mathrm{P}$ \\
\hline $\begin{array}{l}\text { The provincial government is not } \\
\text { obtaining community support as a } \\
\text { necessary condition before } \\
\text { implementing a major policy change }\end{array}$ & 3.89 & 3.96 & 3.89 & 3.40 & 3.65 & 4.32 & 3.43 & 4.25 & 3.50 & 3.93 & 3.44 & 6.854 & 621 & .000 \\
\hline $\begin{array}{l}\text { The provincial government continues to } \\
\text { be committed as it always has been to its } \\
\text { role as the major funder of social } \\
\text { services (reversed) }\end{array}$ & 2.34 & 2.63 & 2.20 & 3.05 & 2.64 & 1.68 & 2.48 & 2.45 & 2.92 & 2.51 & 3.00 & 11.82 & 631 & .000 \\
\hline $\begin{array}{l}\text { Corporations in the province are not } \\
\text { making donating to the voluntary sector } \\
\text { enough of a priority }\end{array}$ & 3.97 & 4.20 & 3.50 & 3.83 & 3.35 & 4.06 & 4.16 & 3.93 & 3.84 & 3.89 & 4.00 & 3.693 & 621 & .000 \\
\hline INDEX & 27.2 & 26.9 & 26.1 & 25.4 & 26.9 & 28.8 & 27.0 & 26.4 & 25.8 & 27.5 & 25.7 & 6.343 & 584 & .000 \\
\hline
\end{tabular}

* The higher the score, the higher the level of dissatisfaction with the external environment. 
Table 5. Impact of Environmental Changes: Mean scores for the total sample and each province*

\begin{tabular}{|c|c|c|c|c|c|c|c|c|c|c|c|c|c|c|}
\hline $\begin{array}{c}\text { As a result of the current environment, } \\
\text { does your organization feel.... }\end{array}$ & Total & $\mathrm{BC}$ & $\mathrm{AB}$ & SK & $\mathrm{MN}$ & $\mathrm{ON}$ & QB & NB & $\mathrm{PE}$ & NS & NF & $\mathrm{F}$ & Df & $\mathrm{P}$ \\
\hline the need to make better use of staff skills & 3.77 & 3.72 & 3.91 & 3.60 & 3.97 & 3.67 & 4.11 & 3.52 & 3.50 & 3.60 & 3.96 & 1.896 & 616 & .050 \\
\hline an increased sense of vulnerability & 3.55 & 3.56 & 3.47 & 3.59 & 3.45 & 3.71 & 3.60 & 2.98 & 3.04 & 3.73 & 3.60 & 1.809 & 642 & .064 \\
\hline $\begin{array}{l}\text { a greater need to address organizational } \\
\text { inefficiencies }\end{array}$ & 3.40 & 3.31 & 3.34 & 3.43 & 3.73 & 3.43 & 3.47 & 2.87 & 3.19 & 3.60 & 3.68 & 1.551 & 633 & .127 \\
\hline $\begin{array}{l}\text { the need to participate in for-profit } \\
\text { activities to support nonprofit work }\end{array}$ & 3.14 & 3.33 & 3.27 & 3.52 & 3.24 & 3.20 & 2.88 & 2.96 & 2.85 & 3.14 & 2.83 & 1.199 & 628 & .292 \\
\hline $\begin{array}{l}\text { that funders do not think the needs of } \\
\text { your clients are a priority }\end{array}$ & 2.99 & 2.88 & 2.89 & 3.07 & 2.83 & 3.18 & 3.38 & 2.39 & 2.73 & 2.44 & 2.91 & 3.014 & 626 & .002 \\
\hline $\begin{array}{l}\text { the need to cover service areas } \\
\text { previously taken care of by other } \\
\text { agencies }\end{array}$ & 2.98 & 3.06 & 3.61 & 3.09 & 3.20 & 2.98 & 2.40 & 2.61 & 2.62 & 3.77 & 3.24 & 4.799 & 626 & .000 \\
\hline
\end{tabular}

* The higher the score, the more strongly is the impact felt. 
Table 6. Organizational changes made in response to impacts: Mean scores for the total sample and each province*

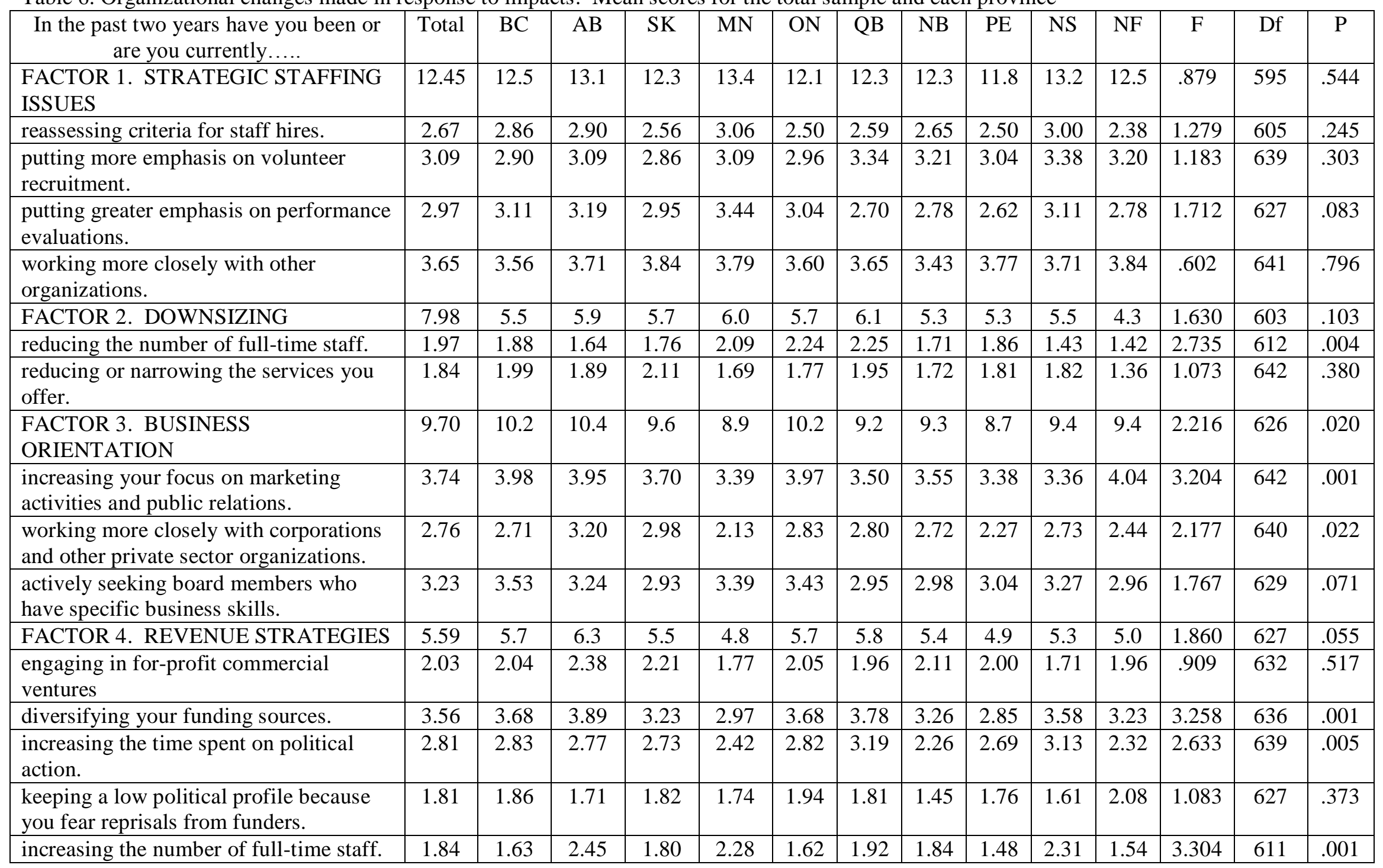

*The higher the score, the more substantial the change. 
Table 7: Number of inter-organizational relationships for each province

\begin{tabular}{|l|c|}
\hline Province & Mean Number of Relationships \\
\hline British Columbia (BC) & 4.88 \\
\hline Alberta (AB) & 4.89 \\
\hline Saskatchewan (SK) & 4.86 \\
\hline Manitoba (MN) & 4.48 \\
\hline Ontario (ON) & 5.13 \\
\hline Quebec (QB) & 4.65 \\
\hline New Brunswick (NB) & 4.38 \\
\hline Prince Edward Island (PE) & 4.77 \\
\hline Nova Scotia (NS) & 4.89 \\
\hline Newfoundland (NF) & 4.60 \\
\hline
\end{tabular}

Table 8: Reasons for Collaboration: Ranking of items for total sample

\begin{tabular}{|l|c|}
\hline How important a motivator is..... & Ranking \\
\hline drawing more attention to an issue or problem through strength in numbers & 1 \\
\hline achieving greater community involvement & 2 \\
\hline providing more integrated services & 3 \\
\hline keeping all the organizations providing similar services solvent & 4 \\
\hline reducing current operating costs & 5 \\
\hline sharing the risk when starting a new program or project & 6 \\
\hline satisfying government requirements for funding & 7 \\
\hline becoming more independent from the government & 8 \\
\hline
\end{tabular}


Table 9. Inter-organizational Relations: Mean scores for the total sample and each province*

\begin{tabular}{|c|c|c|c|c|c|c|c|c|c|c|c|c|c|c|}
\hline $\begin{array}{l}\text { Statements About How Organizations Relate to } \\
\text { Each Other }\end{array}$ & Total & $\mathrm{BC}$ & $\mathrm{AB}$ & SK & MN & ON & QB & NB & $\mathrm{PE}$ & NS & $\mathrm{NF}$ & $\mathrm{F}$ & $\overline{D f}$ & $\mathrm{P}$ \\
\hline $\begin{array}{l}\text { FACTOR 1: PREDISPOSING CONDITIONS } \\
\text { FOR COLLABORATION }\end{array}$ & 6.64 & 6.6 & 6.8 & 7.4 & 7.1 & 6.7 & 6.0 & 6.8 & 6.6 & 7.0 & 6.6 & 2.228 & 625 & .019 \\
\hline $\begin{array}{l}\text { Collaborative arrangements are less appealing to } \\
\text { organizations when times are good. }\end{array}$ & 3.28 & 3.39 & 3.33 & 3.67 & 3.53 & 3.34 & 2.80 & 3.28 & 3.54 & 3.09 & 3.56 & 3.230 & 628 & .001 \\
\hline $\begin{array}{l}\text { Collaborative enterprises are less important for } \\
\text { organizations that are financially independent. }\end{array}$ & 3.36 & 3.23 & 3.44 & 3.75 & 3.55 & 3.33 & 3.17 & 3.51 & 3.31 & 3.42 & 3.48 & 1.130 & 635 & .339 \\
\hline FACTOR 2: STRUCTURAL BIAS & 8.47 & 8.4 & 9.1 & 8.6 & 8.9 & 7.9 & 8.3 & 9.1 & 8.5 & 9.1 & 9.2 & 1.904 & 584 & .049 \\
\hline $\begin{array}{l}\text { It is easier to collaborate with an organization } \\
\text { mostly run by women, because hierarchy and } \\
\text { control are less important to women than to men. }\end{array}$ & 2.69 & 2.55 & 2.87 & 2.72 & 2.97 & 2.66 & 2.59 & 2.70 & 2.62 & 2.86 & 2.72 & .503 & 625 & .873 \\
\hline $\begin{array}{l}\text { Organizations that have a collective structure are } \\
\text { better partners than those with a hierarchical } \\
\text { structure. }\end{array}$ & 3.05 & 3.08 & 3.18 & 3.34 & 3.29 & 2.71 & 2.97 & 3.32 & 3.31 & 3.43 & 3.40 & 2.904 & 620 & .002 \\
\hline $\begin{array}{l}\text { Partnerships are a way for large organizations to } \\
\text { build empires. }\end{array}$ & 2.69 & 2.81 & 2.96 & 2.57 & 2.63 & 2.50 & 2.69 & 2.98 & 2.62 & 2.66 & 3.04 & 1.268 & 613 & .251 \\
\hline $\begin{array}{l}\text { FACTOR 3: COLLABORATIVE } \\
\text { COMPLEMENTARITY }\end{array}$ & 11.4 & 11.0 & 11.2 & 11.2 & 11.3 & 11.4 & 11.7 & 11.9 & 11.2 & 11.1 & 11.6 & 1.063 & 631 & .388 \\
\hline $\begin{array}{l}\text { The most important ingredient in a successful } \\
\text { collaboration is shared purpose. }\end{array}$ & 4.54 & 4.44 & 4.51 & 4.52 & 4.45 & 4.63 & 4.48 & 4.47 & 4.42 & 4.62 & 4.80 & 1.030 & 643 & .414 \\
\hline $\begin{array}{l}\text { As long as collaborating organizations share } \\
\text { common values, it is easy to compromise on the } \\
\text { means to reaching the desired ends. }\end{array}$ & 3.63 & 3.34 & 3.64 & 3.70 & 3.58 & 3.64 & 3.72 & 3.96 & 3.69 & 3.27 & 3.84 & 1.793 & 640 & .066 \\
\hline $\begin{array}{l}\text { Large organizations can collaborate well with } \\
\text { small organizations because they have } \\
\text { complementary skills. }\end{array}$ & 3.23 & 3.23 & 3.09 & 2.98 & 3.31 & 3.17 & 3.46 & 3.49 & 3.04 & 3.23 & 3.00 & 1.377 & 634 & .195 \\
\hline FACTOR 4: COMPETITION & 6.63 & 6.7 & 6.6 & 6.6 & 6.6 & 7.0 & 5.9 & 7.2 & 6.3 & 6.4 & 7.0 & 2.833 & 623 & .003 \\
\hline $\begin{array}{l}\text { Having to compete for scarce resources can have } \\
\text { a positive influence on an organization. }\end{array}$ & 3.02 & 2.99 & 3.09 & 2.95 & 2.94 & 3.12 & 2.68 & 3.51 & 3.04 & 2.93 & 3.16 & 1.801 & 637 & .065 \\
\hline $\begin{array}{l}\text { To survive in this climate, organizations must } \\
\text { look for a competitive edge. }\end{array}$ & 3.60 & 3.70 & 3.51 & 3.64 & 3.47 & 3.86 & 3.22 & 3.73 & 3.31 & 3.43 & 3.83 & 2.671 & 628 & .005 \\
\hline $\begin{array}{l}\text { Small organizations do not like collaborating with } \\
\text { large organizations because they fear } \\
\text { amalgamation. }\end{array}$ & 2.82 & 2.85 & 2.73 & 2.84 & 3.00 & 2.82 & 2.75 & 2.93 & 2.77 & 2.86 & 2.80 & .179 & 624 & .996 \\
\hline
\end{tabular}

* The higher the score, the higher the level of agreement with the statement. 
Table 10. Perceptions of the Future: Mean scores for the total sample and each province*

\begin{tabular}{|c|c|c|c|c|c|c|c|c|c|c|c|c|c|c|}
\hline Statements About the Environment & Total & $\mathrm{BC}$ & $\mathrm{AB}$ & SK & $\mathrm{MN}$ & ON & QB & NB & $\mathrm{PE}$ & NS & $\mathrm{NF}$ & $\mathrm{F}$ & Df & $\mathrm{P}$ \\
\hline FACTOR 1. PESSIMISTIC OUTLOOK & 14.2 & 13.9 & 14.5 & 12.81 & 14.5 & 15.0 & 13.2 & 14.6 & 13.6 & 14.5 & 14.7 & 3.796 & 616 & .000 \\
\hline $\begin{array}{l}\text { In the future, fewer smaller organizations will } \\
\text { exist. }\end{array}$ & 3.26 & 3.23 & 3.38 & 2.93 & 3.13 & 3.47 & 2.73 & 3.74 & 3.31 & 3.60 & 3.32 & 4.241 & 633 & .000 \\
\hline $\begin{array}{l}\text { In the future, the situation for the marginalized } \\
\text { groups in society will only get worse. }\end{array}$ & 3.85 & 3.69 & 3.93 & 3.34 & 4.06 & 4.06 & 3.90 & 3.70 & 3.62 & 3.82 & 3.84 & 2.506 & 637 & .008 \\
\hline In the future, more organizations will be merging. & 3.44 & 3.45 & 3.51 & 3.45 & 3.47 & 3.65 & 2.98 & 3.48 & 3.08 & 3.43 & 4.00 & 4.359 & 628 & .000 \\
\hline $\begin{array}{l}\text { In the future, the government will try to exert } \\
\text { more control over the action and priorities of the } \\
\text { voluntary sector. }\end{array}$ & 3.64 & 3.63 & 3.57 & 3.05 & 3.75 & 3.84 & 3.63 & 3.62 & 3.44 & 3.69 & 3.52 & 1.841 & 633 & .058 \\
\hline FACTOR 2. COMMUNITY ACTIVISM & 10.9 & 10.9 & 11.0 & 11.5 & 11.3 & 10.7 & 10.8 & 11.2 & 11.2 & 11.0 & 10.9 & .841 & 595 & .578 \\
\hline $\begin{array}{l}\text { In the future, more voluntary organizations will be } \\
\text { taking an active role in political action on behalf } \\
\text { of the sector. }\end{array}$ & 3.76 & 3.74 & 3.78 & 3.77 & 3.78 & 3.81 & 3.71 & 3.64 & 3.65 & 3.89 & 3.64 & .310 & 632 & .972 \\
\hline $\begin{array}{l}\text { In the future, clients will be more involved in the } \\
\text { decision-making process of voluntary } \\
\text { organizations. }\end{array}$ & 3.55 & 3.57 & 3.58 & 3.77 & 3.81 & 3.46 & 3.40 & 3.51 & 3.69 & 3.67 & 3.72 & 1.214 & 625 & .283 \\
\hline $\begin{array}{l}\text { In the future, voluntary organizations devote more } \\
\text { time and effort toward building a civil society. }\end{array}$ & 3.65 & 3.60 & 3.66 & 3.95 & 3.79 & 3.50 & 3.64 & 4.00 & 3.81 & 3.48 & 3.56 & 1.818 & 615 & .062 \\
\hline FACTOR 3. OPTIMISTIC OUTLOOK & 5.89 & 5.7 & 6.1 & 6.0 & 5.6 & 5.5 & 6.1 & 6.6 & 5.9 & 6.4 & 5.8 & 3.177 & 621 & .001 \\
\hline $\begin{array}{l}\text { As the economy gets better, governments will } \\
\text { revert back to their previous levels of support for } \\
\text { the voluntary sector. }\end{array}$ & 2.31 & 2.27 & 2.45 & 2.45 & 2.22 & 2.14 & 2.32 & 2.74 & 2.35 & 2.40 & 2.08 & 1.588 & 627 & .115 \\
\hline $\begin{array}{l}\text { In the future, there will be a greater appreciation } \\
\text { of the contribution of the voluntary sector in the } \\
\text { community. }\end{array}$ & 3.58 & 3.48 & 3.67 & 3.51 & 3.39 & 3.34 & 3.77 & 3.87 & 3.58 & 4.00 & 3.72 & 1.214 & 625 & .283 \\
\hline FACTOR 4. PARTNERSHIP & 7.12 & 7.1 & 7.7 & 7.0 & 7.4 & 7.1 & 6.8 & 7.3 & 7.4 & 7.2 & 7.2 & 1.822 & 627 & .061 \\
\hline $\begin{array}{l}\text { In the future, more voluntary organizations will be } \\
\text { formally working together to strengthen each } \\
\text { others' activities. }\end{array}$ & 3.88 & 4.44 & 4.51 & 4.52 & 4.45 & 4.63 & 4.48 & 4.47 & 4.42 & 4.62 & 4.80 & 1.030 & 643 & .414 \\
\hline $\begin{array}{l}\text { In the future, the corporate sector will become } \\
\text { more involved in partnerships with voluntary } \\
\text { organizations. }\end{array}$ & 3.24 & 3.18 & 3.73 & 3.16 & 3.35 & 3.22 & 2.93 & 3.45 & 3.31 & 3.50 & 3.25 & 2.806 & 631 & .003 \\
\hline FACTOR 5. MANAGEMENT STRATEGY & 9.98 & 9.9 & 10.4 & 10.1 & 10.1 & 10.4 & 8.8 & 10.2 & 9.3 & 10.2 & 11.1 & 4.074 & 627 & .000 \\
\hline $\begin{array}{l}\text { In the future, voluntary organizations will have to } \\
\text { be involved in commercial ventures that generate } \\
\text { profits. }\end{array}$ & 3.48 & 3.52 & 3.71 & 3.41 & 3.41 & 3.57 & 3.05 & 3.80 & 3.19 & 3.56 & 3.96 & 3.310 & 636 & .001 \\
\hline $\begin{array}{l}\text { In the future, voluntary organizations will put } \\
\text { more focus on management control, marketing } \\
\text { and entrepreneurship. }\end{array}$ & 3.68 & 3.80 & 3.87 & 3.74 & 3.76 & 4.00 & 3.04 & 3.63 & 3.35 & 3.59 & 4.04 & 7.760 & 638 & .000 \\
\hline $\begin{array}{l}\text { Although traditionally organizations in the } \\
\text { voluntary sector have been advocates for the }\end{array}$ & 2.81 & 2.61 & 2.84 & 2.95 & 2.88 & 2.84 & 2.67 & 2.77 & 2.81 & 3.09 & 3.12 & .852 & 633 & .568 \\
\hline
\end{tabular}


common good, in the future they will have to

narrow their focus to concentrate on serving their

own members and constituents.

* The higher the score, the higher the level of agreement with the statement. 


\section{i_Ontario Documentation}

Total Grants/Transfers:

Total Transfer Payments

Summary of Expenditure by Standard Accounts Classification and Ministry

Ontario Public Accounts 1989-1990 to 1999-2000

Social Expenditure:

Health + Social Services

\section{Financial Highlights}

Ontario Public Accounts 1990-1991 to 1992-1993

Health + Social Services

Statement of Operations and Accumulated Deficit

Ontario Public Accounts 1993-1994 to 1999-2000

Ministry Expenditure:

Transfer Payments for Community and Social Services

Summary of Expenditure by Standard Accounts Classification and Ministry

Ontario Public Accounts 1989-1990 V. 1 to 1999-2000

\section{i_Manitoba Documentation}

Total Grants/Transfers:

Total Grants/Transfer Payments

Summary of Expenditure by Department and Expenditure Object Code

Manitoba Public Accounts 1989-1990 to 1999-2000

Social Expenditure:

Health + Family Services

Consolidated Statement of Revenue and Expenditure

Manitoba Public Accounts 1989-1990 to 1999-2000

Ministry Expenditure:

Family Services

(Grants/Transfer Payments)

Summary of Expenditure by Department and Expenditure Object Code

Manitoba Public Accounts 1989-1990

Community Support Programs + Family Services

(Grants/Transfer Payments)

Summary of Expenditure by Department and Expenditure Object Code

Manitoba Public Accounts 1990-1991 to 1999-2000

\section{i Saskatchewan Documentation}

Total Grants/Transfers:

Total Grants

(for all ministries)

Saskatchewan Public Accounts 1989-1990 to 1990-1991

Grants and Contributions

Expenses by Object

Saskatchewan Public Accounts 1991-1992 to 1992-1993

Total Transfers

Schedule of Expenditure by Department and Object

Saskatchewan Public Accounts 1993-1994 to 1999-2000

Social Expenditure:

Health + Social Services

Statement of Operations and Accumulated Deficit

Saskatchewan Public Accounts 1989-1990 to 1992-1993

Community Development + Health + Social Services and Assistance 
Expenses by Function and by Object

Saskatchewan Public Accounts 1993-1994 to 1999-2000

Ministry Expenditure:

Social Services

(Grants)

Saskatchewan Public Accounts 1989-1990 to 1991-1992

Social Services

(Transfers)

Schedule of Expenditure by Department and Object

Saskatchewan Public Accounts 1992-1993 to 1999-2000

\section{i Alberta Documentation \\ Total Grants/Transfers: \\ Total Grants \\ Details of Expenditure by Object}

Alberta Public Accounts 1989-1990 to 1996-1997

Grants

Expenses by Object

Alberta Public Accounts 1997-1998 to 1999-2000

Social Expenditure:

Health + Social Services

Consolidated Statement of Revenue and Expenditure

Alberta Public Accounts 1989-1990 to 1994-1995

Health + Social Services

Consolidated Fiscal Summary

Alberta Public Accounts 1995-1996

Health + Social Services

Consolidated Statement of Operations

Alberta Public Accounts 1996-1997 to 1999-2000

Ministry Expenditure:

Family and Social Services

Total Grants

Details of Expenditure by Object

Alberta Public Accounts 1989-1990 to 1996-1997

Social Services

(Grants)

Alberta Gaming and Liquor Commission

For the years 1997-1998 to 1999-2000

Non-Profit Expenditure:

Total Grants to Non-Profit Organizations

Details of Expenditure by Object

Alberta Public Accounts 1989-1990 to 1990-1991, 1992-1992 to 1996-1997

\section{i British Columbia Documentation}

Total Grants/Transfers:

Total Grants and Contributions

Schedule of Expenditure by Group Account Classification

British Columbia Public Accounts 1989-1990 to 1999-2000

Social Expenditure:

Health + Social Services

Statement of Revenue and Expenditure

British Columbia Public Accounts 1989-1990 to 1994-1995

Health + Social Services

Statement of Operations

British Columbia Public Accounts 1996-1997 
$(\%$ Health $+\%$ Social Services $) *$ Total Expenditure

Summary Overview

British Columbia Public Accounts 1995-1996, 1997-1998 to 1999-2000

Ministry Expenditure:

Social Services

Schedule of Expenditure by Group Account Classification

British Columbia Public Accounts 1989-1990 to 1995-1996

Children and Families

Schedule of Expenditure by Group Account Classification

British Columbia Public Accounts 1996-1997 to 1998-1999

Children and Families + Community Development + Social Development

Schedule of Expenditure by Group Account Classification

British Columbia Public Accounts 1999-2000 